Occurrence and Transport of Cadmium, Lead, and Zinc in the Spokane River Basin, Idaho and Washington, Water Years 1999-2001

Water-Resources Investigations Report 02-4183
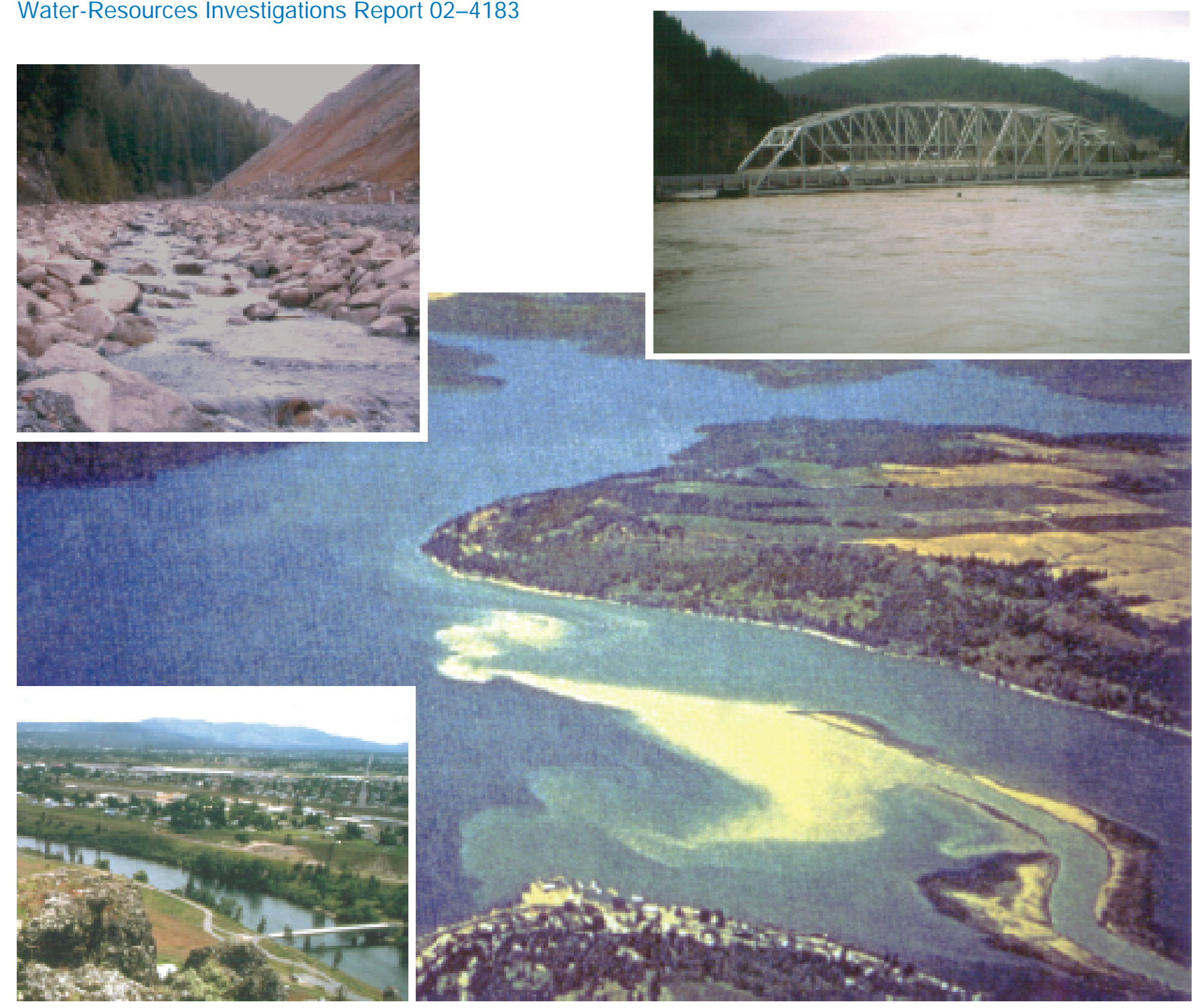

NATIONAL WATER-QUALITY ASSESSMENT PROGRAM

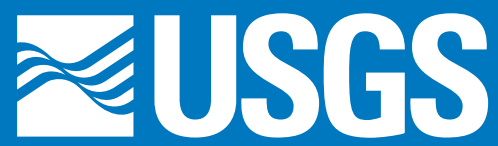


Cover photos: Top left, mine tailings on the East Fork of Ninemile Creek; top right, Coeur d'Alene River near Cataldo during rain-on-snow event; center, discharge of metal-enriched sediment entering Coeur d'Alene Lake from the Coeur d'Alene River; bottom left, Spokane River near Spokane. 


\section{Occurrence and Transport of Cadmium, Lead, and Zinc in the Spokane River Basin, Idaho and Washington, Water Years 1999-2001}

By Gregory M. Clark

Water-Resources Investigations Report 02-4183

Boise, Idaho

2003 


\section{U.S. DEPARTMENT OF THE INTERIOR \\ GAIL A. NORTON, Secretary}

\section{U.S. GEOLOGICAL SURVEY}

Charles G. Groat, Director

Any use of firm, trade, and brand names in this report is for identification purposes only and does not constitute endorsement by the U.S. Government.

Additional information can be obtained from:

District Chief

U.S. Geological Survey

230 Collins Road

Boise, ID 83702-4520

http://idaho.usgs.gov

Copies of this report also are available in PDF format, which can be viewed using Adobe Acrobat Reader, at URL:

http://idaho.usgs.gov/public/reports.html
Copies of this report can be purchased from:

U.S. Geological Survey

Information Services

Box 25286

Federal Center

Denver, CO 80225

e-mail: infoservices@usgs.gov 


\section{FOREWORD}

The U.S. Geological Survey (USGS) is committed to serve the Nation with accurate and timely scientific information that helps enhance and protect the overall quality of life, and facilitates effective management of water, biological, energy, and mineral resources (http://www.usgs.gov/). Information on the quality of the Nation's water resources is of critical interest to the USGS because it is so integrally linked to the long-term availability of water that is clean and safe for drinking and recreation and that is suitable for industry, irrigation, and habitat for fish and wildlife. Escalating population growth and increasing demands for the multiple water uses make water availability, now measured in terms of quantity and quality, even more critical to the long-term sustainability of our communities and ecosystems.

The USGS implemented the National Water-Quality Assessment (NAWQA) Program to support national, regional, and local information needs and decisions related to water-quality management and policy (http://water.usgs.gov/nawqa/). Shaped by and coordinated with ongoing efforts of other Federal, State, and local agencies, the NAWQA Program is designed to answer: What is the condition of our Nation's streams and ground water? How are the conditions changing over time? How do natural features and human activities affect the quality of streams and ground water, and where are those effects most pronounced? By combining information on water chemistry, physical characteristics, stream habitat, and aquatic life, the NAWQA Program aims to provide sciencebased insights for current and emerging water issues and priorities. NAWQA results can contribute to informed decisions that result in practical and effective water-resource management and strategies that protect and restore water quality.

Since 1991, the NAWQA Program has implemented interdisciplinary assessments in more than 50 of the Nation's most important river basins and aquifers, referred to as Study Units (http://water.usgs.gov/nawqa/nawqamap.html). Collectively, these Study Units account for more than 60 percent of the overall water use and population served by public water supply, and are representative of the Nation's major hydrologic landscapes, priority ecological resources, and agricultural, urban, and natural sources of contamination.

Each assessment is guided by a nationally consistent study design and methods of sampling and analysis. The assessments thereby build local knowledge about water-quality issues and trends in a particular stream or aquifer while providing an understanding of how and why water quality varies regionally and nationally. The consistent, multi-scale approach helps to determine if certain types of water-quality issues are isolated or pervasive, and allows direct comparisons of how human activities and natural processes affect water quality and ecological health in the Nation's diverse geographic and environmental settings. Comprehensive assessments on pesticides, nutrients, volatile organic compounds, trace metals, and aquatic ecology are developed at the national scale through comparative analysis of the Study-Unit findings (http://water.usgs.gov/nawqa/natsyn.html).

The USGS places high value on the communication and dissemination of credible, timely, and relevant science so that the most recent and available knowledge about water resources can be applied in management and policy decisions. We hope this NAWQA publication will provide you the needed insights and information to meet your needs, and thereby foster increased awareness and involvement in the protection and restoration of our Nation's waters.

The NAWQA Program recognizes that a national assessment by a single program cannot address all waterresource issues of interest. External coordination at all levels is critical for a fully integrated understanding of watersheds and for cost-effective management, regulation, and conservation of our Nation's water resources. The Program, therefore, depends extensively on the advice, cooperation, and information from other Federal, State, interstate, Tribal, and local agencies, non-government organizations, industry, academia, and other stakeholder groups. The assistance and suggestions of all are greatly appreciated.

Robert M. Hirsch

Associate Director for Water 


\section{CONTENTS}

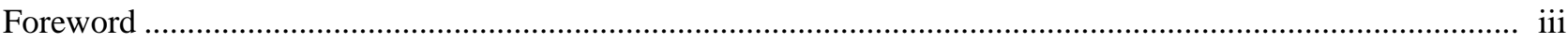

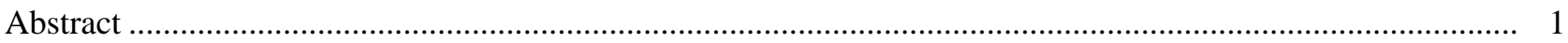

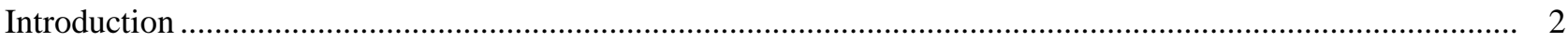

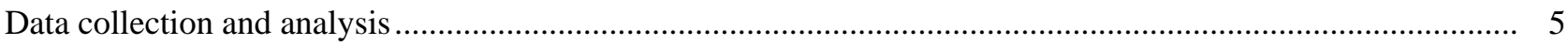

Stream discharge

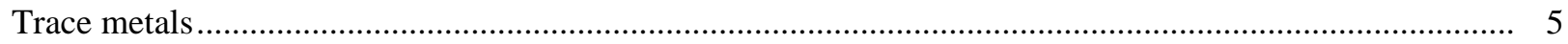

Method for simulating trace-metal loads ........................................................................................... 8

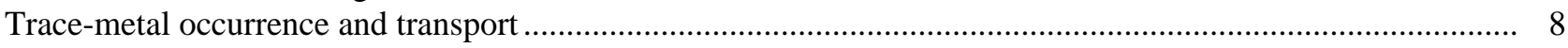

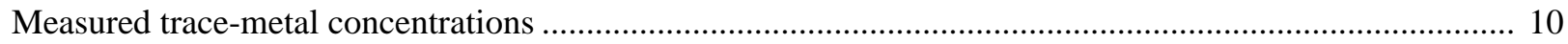

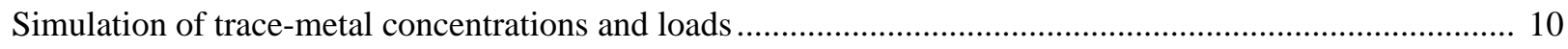

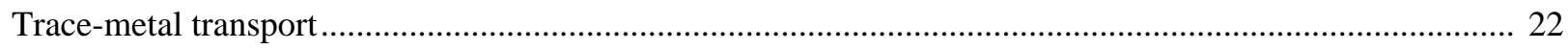

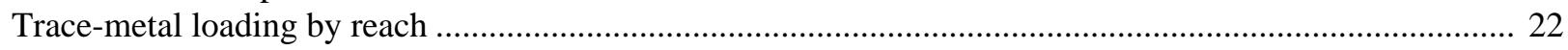

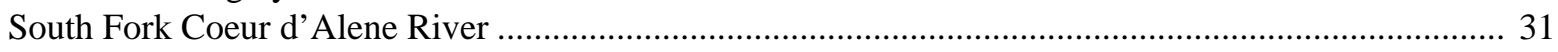

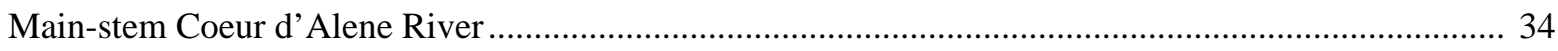

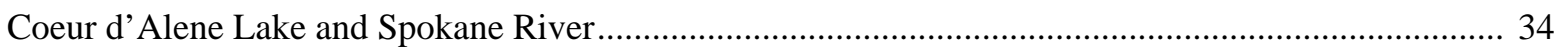

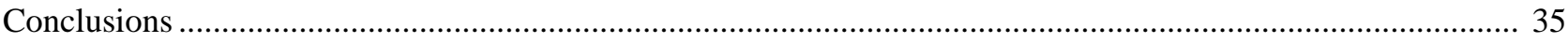

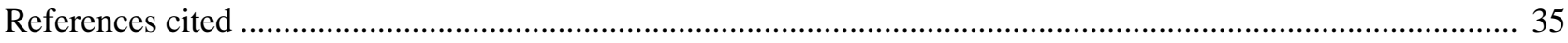

\section{FIGURES}

1. Map showing locations of streamflow-gaging stations and the Spokane River Basin, Idaho and Washington

2. Map showing locations of streamflow-gaging stations on and near the South Fork Coeur d'Alene River, Idaho

3-10. Graphs showing:

3. Stream discharge and sample collection dates at three streamflow-gaging stations in the Spokane River Basin, Idaho and Washington, water years 1999-2001

4. Relation between trace-metal concentrations and stream discharge at streamflow-gaging station 11 on the South Fork Coeur d'Alene River near Pinehurst, Idaho, water years 1999-2001

5. Dissolved and total cadmium, lead, and zinc concentrations in water samples collected at main-stem and tributary streamflow-gaging stations in the Spokane River Basin, Idaho and Washington, water years 1999-2001

6. Stream discharge and measured and simulated concentrations of total lead and dissolved zinc at streamflow-gaging station 11 on the South Fork Coeur d'Alene River near Pinehurst, Idaho, water years 1999-2001.

7. Measured and simulated loads of total cadmium at four streamflow-gaging stations in the Spokane River Basin, Idaho and Washington, water years 1999-2001

8. Measured and simulated loads of total lead at four streamflow-gaging stations in the Spokane River Basin, Idaho and Washington, water years 1999-2001

9. Measured and simulated loads of total zinc at four streamflow-gaging stations in the Spokane River Basin, Idaho and Washington, water years 1999-2001.

10. Mean annual stream discharge and mean annual loads of total cadmium, lead, and zinc at main-stem and tributary streamflow-gaging stations in the Spokane River Basin, Idaho and Washington, water years 1999-2000 
11-13. Diagrams showing:

11. Mean annual stream discharge, mean flow-weighted concentration, and mean annual load of total cadmium for main-stem and tributary streamflow-gaging stations in the Spokane River Basin, Idaho and Washington, water years 1999-2000

12. Mean annual stream discharge, mean flow-weighted concentration, and mean annual load of total cadmium for main-stem and tributary streamflow-gaging stations in the Spokane River Basin, Idaho and Washington, water years 1999-2000

13. Mean annual stream discharge, mean flow-weighted concentration, and mean annual load of total cadmium for main-stem and tributary streamflow-gaging stations in the Spokane River Basin, Idaho and Washington, water years 1999-2000

\section{TABLES}

1. Streamflow-gaging stations in the Spokane River Basin, Idaho and Washington, where stream discharge and water-quality samples were collected to simulate concentrations and loads of cadmium, lead, and zinc, water years 1999-2001

2. Regression coefficients and coefficients of determination $\left(\mathrm{r}^{2}\right)$ for load models used to simulate dissolved and total cadmium, lead, and zinc loads at streamflow-gaging stations in the Spokane River Basin, Idaho and Washington, water years 1999-2001

3. Simulated mean flow-weighted concentrations of cadmium, lead, and zinc at streamflowgaging stations in the Spokane River Basin, Idaho and Washington, water years 1999-2000

4. Simulated annual loads of cadmium, lead, and zinc at streamflow-gaging stations in the Spokane River Basin, Idaho and Washington, water years 1999-2001

5. Simulated mean annual loads of cadmium, lead, and zinc at streamflow-gaging stations in the Spokane River Basin, Idaho and Washington, water years 1999-2000.

6. Mean annual gains and (or) losses of stream discharge and cadmium, lead, and zinc loads in main-stem reaches of the South Fork Coeur d'Alene, Coeur d'Alene, and Spokane Rivers, Idaho and Washington, water years 1999-2000

\section{CONVERSION FACTORS AND ABBREVIATED WATER-QUALITY UNITS}

\begin{tabular}{rll}
\hline Multiply & By & To obtain \\
\hline cubic foot per second $\left(\mathrm{ft}^{3} / \mathrm{s}\right)$ & 0.02832 & cubic meter per second \\
foot $(\mathrm{ft})$ & 0.3048 & meter \\
mile $(\mathrm{mi})$ & 1.609 & kilometer \\
pound per day $(\mathrm{lb} / \mathrm{d})$ & 0.4536 & kilogram per day \\
pound per year $(\mathrm{lb} / \mathrm{yr})$ & 0.4536 & kilogram per year \\
square mile $\left(\mathrm{mi}^{2}\right)$ & 2.590 & square kilometer \\
ton & 0.9072 & metric ton \\
\hline
\end{tabular}

\footnotetext{
Abbreviated water-quality units:

$\mu \mathrm{g} / \mathrm{L}$ micrograms per liter

$\mu \mathrm{m}$ micrometer

$\mathrm{mL}$ milliliter
} 


\title{
Occurrence and Transport of Cadmium, Lead, and Zinc in the Spokane River Basin, Idaho and Washington, Water Years 1999-2001
}

\author{
By Gregory M. Clark
}

\section{Abstract}

A water-quality investigation of the Clark Fork-Pend Oreille and Spokane River Basins began in 1997 as part of the U.S. Geological Survey National Water-Quality Assessment Program. As part of the investigation, selected streams in the Spokane River Basin were sampled for trace metals during water years 1999-2001. These data, combined with data collected as part of a U.S. Environmental Protection Agency Remedial Investigation/Feasibility Study, were used to assess the occurrence, loads, and transport of cadmium, lead, and zinc at 21 streamflow-gaging stations in the Spokane River Basin.

Concentrations of dissolved and total cadmium, lead, and zinc varied widely both at and among stations. At most stations, dissolved cadmium and zinc composed most of the total concentrations; dissolved lead generally composed less than 10 percent of the total lead concentration. From the South Fork Coeur d'Alene River near Mullan downstream to the South Fork Coeur d'Alene River near Pinehurst, concentrations of trace metals increased 2 to 4 orders of magnitude. The mean flow-weighted concentrations of total cadmium, lead, and zinc near Pinehurst for water years 1999-2001 were 5.7, 80, and 810 micrograms per liter $(\mu \mathrm{g} / \mathrm{L})$, respectively. On the Coeur d'Alene River near Harrison, downstream from the confluence of the metal-enriched South Fork and the relatively dilute North Fork Coeur d'Alene River, the mean flow-weighted concentrations of total cadmium, lead, and zinc were 1.6, 88, and $240 \mu \mathrm{g} / \mathrm{L}$, respectively. Trace-metal concentrations were smaller in the Spokane River than in the
Coeur d'Alene River because of dilution and retention in Coeur d'Alene Lake. The mean flowweighted concentrations of total cadmium, lead, and zinc in the Spokane River near Post Falls were $0.32,3.1$, and $71 \mu \mathrm{g} / \mathrm{L}$, respectively.

Regression models relating the mass transport, or load, of trace metals to changes in stream discharge and time were successful in simulating the variability in trace-metal concentrations and loads. The median coefficient of determination for the load models for the 21 stations was largest for total lead (92 percent) and smallest for dissolved and total cadmium ( 82 percent). Whereas most of the cadmium and zinc loads in the Spokane River Basin were derived from the South Fork Coeur d'Alene River, most of the lead load was derived from the Coeur d'Alene River downstream from the confluence of the North and South Forks. Major tributary sources of trace metals to the South Fork Coeur d'Alene River were Canyon Creek, Ninemile Creek, and Government Gulch. These three tributaries contributed about 3,000 pounds of cadmium, 23,000 pounds of lead, and 310,000 pounds of zinc annually to the South Fork Coeur d'Alene River. Erosion and transport of sediment-bound lead in the Coeur d'Alene River was the primary source of total lead, accounting for almost 400,000 pounds annually during water years 1999-2000. Ground-water discharge in the area of the Bunker Hill Superfund site was a major source of zinc in the South Fork Coeur d'Alene River, contributing more than 250,000 pounds per year.

During water years 1999-2000, the average annual loads of cadmium, lead, and zinc transported from the Coeur d'Alene, St. Joe, and St. Maries Rivers to Coeur d'Alene Lake were 8,900, 
500,000, and 1.4 million pounds, respectively. The Coeur d'Alene River accounted for more than 99 percent of the total load of each of these three metals entering the lake. About 4,600 pounds of cadmium, 44,000 pounds of lead, and 980,000 pounds of zinc were transported from Coeur d'Alene Lake into the Spokane River. Between the Spokane River near Post Falls, Idaho, and the Spokane River at Long Lake, Washington, there was an annual net loss of about 2,600,20,000, and 250,000 pounds of cadmium, lead, and zinc, respectively. About 2,000 pounds of cadmium, 24,000 pounds of lead, and 730,000 pounds of zinc were transported annually downstream from Long Lake toward the Columbia River.

\section{INTRODUCTION}

Mining and ore-processing activities conducted since the late 1800s in the South Fork Coeur d'Alene River (SFCDR) Basin have altered the water quality, aquatic biological, and hydrologic conditions in the 6,680-mi ${ }^{2}$ Spokane River Basin of northern Idaho and eastern Washington (fig. 1). Historical ore-processing activities resulted in large quantities of metal-rich tailings that were placed in and along streams (Long, 1998). The tailings have produced, and continue to produce, trace-metal-contaminated water (Hartz, 1993; Woods, 2001a; Woods, 2001b) and extensive deposits of trace-metal-contaminated sediment throughout the SFCDR Basin, the channel and flood plain of the mainstem Coeur d'Alene River (CDR) (Spruill, 1993; Fousek, 1996; Bookstrom and others, 2001), and the lakebed of Coeur d'Alene Lake (Horowitz and others, 1995; Woods and Beckwith, 1997). Annual snowmelt runoff, frequent rain-on-snow events, and occasional floods continue to transport and redistribute tracemetal-contaminated sediments throughout the CDR Basin, into the Spokane River of eastern Washington (Maret and Skinner, 2000; Grosbois and others, 2001), and as far downstream as the Columbia River (Bortleson and others, 1994). The National Sediment Inventory (U.S. Environmental Protection Agency [USEPA], 1997) identified the Coeur d'Alene River and Lake as "areas of probable concern for sediment contamination," the most severe contamination category in their assessment.
Considerable effort is underway to mitigate the adverse environmental effects of past mining in the basin, primarily in the SFCDR valley and its tributaries (Beckwith, 1998). The USEPA is directing cleanup of a 21-mi ${ }^{2}$ Superfund site surrounding the defunct Bunker Hill Mine and ore-processing complex in Kellogg, Idaho (figs. 1 and 2). The State of Idaho, other Federal agencies, and the mining industry also are conducting site-specific sediment-removal, reclamation, and stream-channel rehabilitation projects. The USEPA is evaluating environmental contamination and remediation options in mining-affected areas outside the Superfund site in areas of the lower CDR, its flood plain and adjacent wetlands, and the lakebed of Coeur d'Alene Lake (Beckwith, 1998). In addition, the USEPA and the Idaho Department of Environmental Quality are currently under court order to develop Total Maximum Daily Loads for a number of water bodies that do not support one or more designated uses in the Spokane River Basin as a result of trace-metal contamination.

In 1997, the U.S. Geological Survey (USGS) began a water-quality investigation of the Northern Rockies Intermontane Basins (NROK) encompassing the Clark Fork-Pend Oreille and Spokane River Basins of Montana, Idaho, and Washington (Tornes, 1997). The study was conducted as part of the USGS National Water-Quality Assessment (NAWQA) Program. One of the long-term goals of the program is to identify and describe current water-quality conditions and the factors that affect those conditions (Hirsch and others, 1988). As part of the NROK NAWQA, selected streams in the Spokane River Basin, which includes the CDR, were sampled and analyzed for selected trace metals during water years (WYs) 1999-2001 (October 1, 1998, through September 30, 2001).

The purpose of this report is to describe the occurrence and transport of cadmium, lead, and zinc in numerous stream reaches in the Spokane River Basin in Idaho and Washington. Stream discharge and tracemetal chemistry data were collected at 21 streamflowgaging stations in the basin during WYs 1999-2001 and analyzed to quantify water and trace-metal concentrations and loads. The geographic and temporal distribution of data were sufficient to quantify the absolute and relative mass transport of water and trace metals during most of this time period from numerous tributaries, for most of the main stem of the SFCDR and CDR, into and out of Coeur d'Alene Lake, and for a large part of the Spokane River.

\section{Cadmium, Lead, and Zinc in the Spokane River Basin, Idaho and Washington}




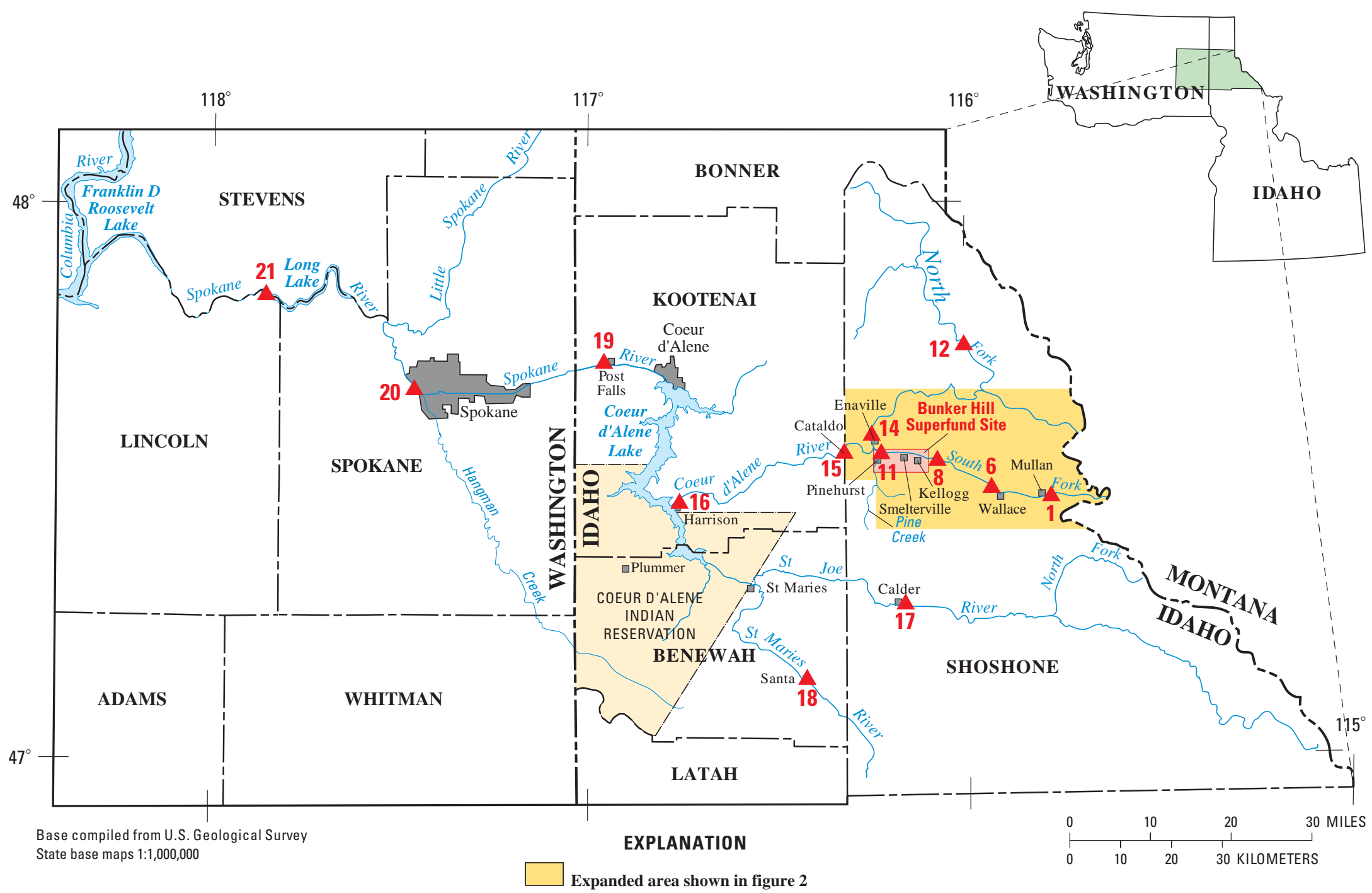

Streamflow-gaging station and number (see table 1)

Figure 1. Locations of streamflow-gaging stations and the Spokane River Basin, Idaho and Washington. 


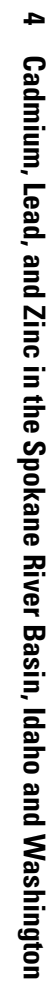

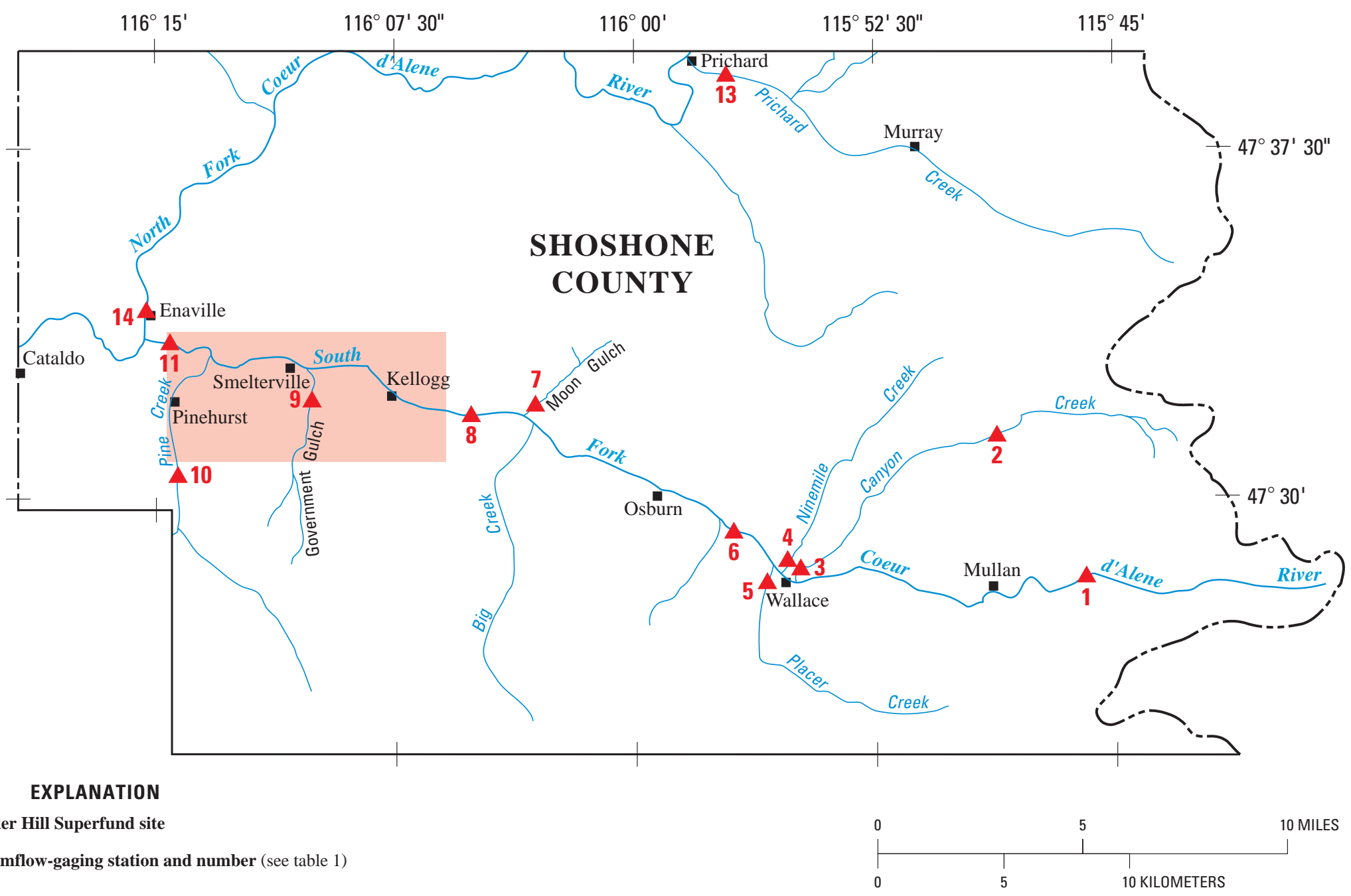

Figure 2. Locations of streamflow-gaging stations on and near the South Fork Coeur d'Alene River, Idaho 


\section{DATA COLLECTION AND ANALYSIS}

\section{Stream Discharge}

Stream discharge at the 21 stations in the station network (figs. 1 and 2) was measured using standard USGS methods (Buchanan and Somers, 1968, 1969;

Carter and Davidian, 1968). For 17 of the 21 stations, stream discharge was measured using a continuous record of water stage calibrated to periodic measurements. However, at 3 (stations 1, 5, and 6) of the 17 stations with stage recorders, collection of continuous record was discontinued on May 1, 2000, because of funding constraints. For these three stations, daily mean stream discharge measured from October 1, 1998, through April 30, 2000, was correlated (indexed) to the daily mean stream discharge at a nearby station (or group of stations) with continuous record. The relation between the two stations then was used to generate the daily mean stream discharge for the discontinued station during the remaining time period for which loads were simulated (table 1). For example, the daily mean stream discharge at station 1 from October 1 , 1998, through April 30, 2000, was indexed to the daily mean stream discharge at station 8 minus the daily mean stream discharge at stations 7, 5, 4, and 3 (table 1). The resultant relation was used to estimate the daily mean stream discharge for station 1 from May 1, 2000, through September 30, 2000.

Stations 2, 7, and 9 were not instrumented with a continuous stage recorder. At these three stations, instantaneous stream discharge was measured over a wide range of water stages coinciding with the collection of water-quality samples. Hydrographs for WYs 1999 and 2000 were generated for stations 2, 7, and 9 by indexing the stream discharge measurements to nearby stations with continuous stream discharge record (table 1). Stream discharge for stations 1, 2, 5-7, and 9 was not estimated for WY 2001.

Station 16 is situated within the backwater created by Coeur d'Alene Lake and, therefore, does not have a valid stage-stream discharge relation. To estimate stream discharge at station 16, the USGS stream discharge model FourPt was used (Delong and others, 1997). The model uses channel geometry and waterstage data at upstream and downstream stations within the stream reach being modeled. The model was calibrated using discharge measurements over a wide range of stream discharge and lake stage and was used to compute a daily mean stream discharge for station 16 for WYs 1999-2001.

\section{Trace Metals}

The trace-metal data used in this report were collected during WYs 1999-2001 as part of two overlapping studies conducted by the USGS. These studies were the NROK NAWQA study and the Remedial Investigation/Feasibility Study (RI/FS) of the Spokane River Basin (Woods, 2001b). Because these studies had somewhat different objectives, the number of samples collected at each station varied, ranging from a minimum of 16 samples collected at 6 stations to a maximum of 51 samples collected at station 11 (table 1). The sampling approach for both the NAWQA and RI/FS studies was to allocate samples over the full range of the station hydrograph to develop a robust relation between trace-metal concentration and stream discharge. In general, samples were collected on a fixed-interval frequency, and additional samples were collected during low or high stream discharge. Additional samples were collected as part of the RI/FS study during significant discharge events such as rain on snow, spring snowmelt runoff, and thunderstorms to characterize trace-metal transport during those time periods. Figure 3 shows the sampling frequency at stations 9,11 , and 16 during the period of study. The sampling frequency at station 9 (Government Gulch at Smelterville) is generally representative of the sampling frequency at 12 of the network stations (stations $1,2,5-7,9,12,13,15,17,18$, and 21). At these 12 stations, samples were collected routinely from October 1998 through March 2000, when sampling was discontinued. Trace-metal loads were simulated only for WYs 1999 and 2000 at these 12 stations. The sampling frequency at station 16 (CDR near Harrison) is representative of five stations in the station network (stations 3, $4,8,10$, and 16). At these five stations, samples were collected as just described; however, sampling was restarted in September 2000 and continued through the remainder of WY 2001 (fig. 3). At these five stations, trace-metal loads were simulated for WYs 1999-2001. The sampling frequency at station 11 generally represents the frequency at four stations in the network (stations $11,14,19$, and 20) that were sampled routinely throughout WYs 1999-2001. Trace-metal loads at these four stations also were simulated for WYs 19992001 (table 1). 
Table 1. Streamflow-gaging stations in the Spokane River Basin, Idaho and Washington, where stream discharge and water-quality samples were collected to simulate concentrations and loads of cadmium, lead, and zinc, water years 1999-2001

[Locations shown in figures 1 and 2; No., number; USGS, U.S. Geological Survey; SFCDR, South Fork Coeur d'Alene River; ID, Idaho; WA, Washington; C, continuous; I, indexed; M, modeled; —, station not indexed; NFCDR, North Fork Coeur d'Alene River; CDR, Coeur d'Alene River]

\begin{tabular}{|c|c|c|c|c|c|c|}
\hline $\begin{array}{c}\text { Station } \\
\text { No. }\end{array}$ & $\begin{array}{c}\text { USGS } \\
\text { station } \\
\text { identificatio } \\
\text { n No. }\end{array}$ & USGS station name & $\begin{array}{l}\text { Type of } \\
\text { stream } \\
\text { discharge } \\
\text { record }\end{array}$ & $\begin{array}{l}\text { Stations used for } \\
\text { stream discharge } \\
\text { indexing }\end{array}$ & $\begin{array}{l}\text { No. of trace- } \\
\text { metal samples } \\
\text { collected }\end{array}$ & $\begin{array}{l}\text { Water years } \\
\text { for which } \\
\text { loads were } \\
\text { simulated }\end{array}$ \\
\hline 1 & 12413040 & SFCDR above Deadman Gulch near Mullan, ID & $\mathrm{C}, \mathrm{I}$ & $8-(7+5+4+3)$ & 19 & $1999-2000$ \\
\hline 2 & 12413118 & Canyon Creek near Burke, ID & I & 3 & 16 & 1999-2000 \\
\hline 3 & 12413125 & Canyon Creek above mouth at Wallace, ID & $\mathrm{C}$ & - & 27 & 1999-2001 \\
\hline 4 & 12413130 & Ninemile Creek above mouth at Wallace, ID & $\mathrm{C}$ & - & 28 & 1999-2001 \\
\hline 5 & 12413140 & Placer Creek at Wallace, ID & $\mathrm{C}, \mathrm{I}$ & 4 & 17 & 1999-2000 \\
\hline 6 & 12413150 & SFCDR at Silverton, ID & $\mathrm{C}, \mathrm{I}$ & $8-7$ & 19 & 1999-2000 \\
\hline 7 & 12413190 & Moon Creek above mouth at Elk Creek, ID & I & 4 & 16 & 1999-2000 \\
\hline 8 & 12413210 & SFCDR at Elizabeth Park near Kellogg, ID & $\mathrm{C}$ & - & 28 & 1999-2001 \\
\hline 9 & 12413290 & Government Gulch near mouth at Smelterville, ID & I & 10 & 16 & 1999-2000 \\
\hline 10 & 12413445 & Pine Creek below Amy Gulch near Pinehurst, ID & $\mathrm{C}$ & - & 28 & 1999-2001 \\
\hline 11 & 12413470 & SFCDR near Pinehurst, ID & $\mathrm{C}$ & - & 51 & 1999-2001 \\
\hline 12 & 12411000 & NFCDR above Shoshone Creek near Prichard, ID & $\mathrm{C}$ & - & 17 & 1999-2000 \\
\hline 13 & 12411935 & Prichard Creek at mouth at Prichard, ID & $\mathrm{C}$ & - & 18 & 1999-2000 \\
\hline 14 & 12413000 & NFCDR at Enaville, ID & $\mathrm{C}$ & - & 48 & 1999-2001 \\
\hline 15 & 12413500 & CDR near Cataldo, ID & $\mathrm{C}$ & - & 19 & 1999-2000 \\
\hline 16 & 12413860 & CDR near Harrison, ID & M & - & 25 & 1999-2001 \\
\hline 17 & 12414500 & St. Joe River at Calder, ID & $\mathrm{C}$ & - & 16 & 1999-2000 \\
\hline 18 & 12414900 & St. Maries River near Santa, ID & $\mathrm{C}$ & - & 16 & 1999-2000 \\
\hline 19 & 12419000 & Spokane River near Post Falls, ID & $\mathrm{C}$ & - & 47 & 1999-2001 \\
\hline 20 & 12424500 & Spokane River at 7-Mile Bridge, WA & $\mathrm{C}$ & - & 24 & 1999-2001 \\
\hline 21 & 12433000 & Spokane River at Long Lake, WA & $\mathrm{C}$ & - & 16 & 1999-2000 \\
\hline
\end{tabular}

Samples at all stations were collected using nonmetallic samplers and cross-sectional, depth-integrated sampling procedures (Edwards and Glysson, 1988). Samples were composited and subsampled using a polyethylene churn or Teflon cone splitting device. Samples for whole-water recoverable (total) analyses were withdrawn directly from the splitting device. Samples for dissolved (smaller than $0.45-\mu \mathrm{m}$ diameter) analyses were withdrawn directly from either the churn splitter or from a subsample of the cone splitter and passed through a pre-rinsed, $0.45-\mu \mathrm{m}$ pore size, disposable Gelman capsule filter. All trace-metal samples were preserved with $2 \mathrm{~mL}$ of Ultrex nitric acid. Samples were shipped in plastic coolers to the USGS National
Water Quality Laboratory (NWQL) in Denver, Colo. About 10 percent of the samples were submitted as blanks, field spikes, and duplicates for quality assurance purposes as described by Friedman and Erdmann (1982) and Mueller and others (1997).

Samples at all stations were analyzed at the NWQL using similar analytical techniques. At the NWQL, samples were analyzed for total and dissolved concentrations of selected trace metals. Samples for total analysis were digested by heating with dilute hydrochloric acid and were filtered prior to analysis. Trace-metal concentrations were determined by atomic absorption spectrometry in conjunction with a graphite furnace and inductively coupled plasma-mass spec- 


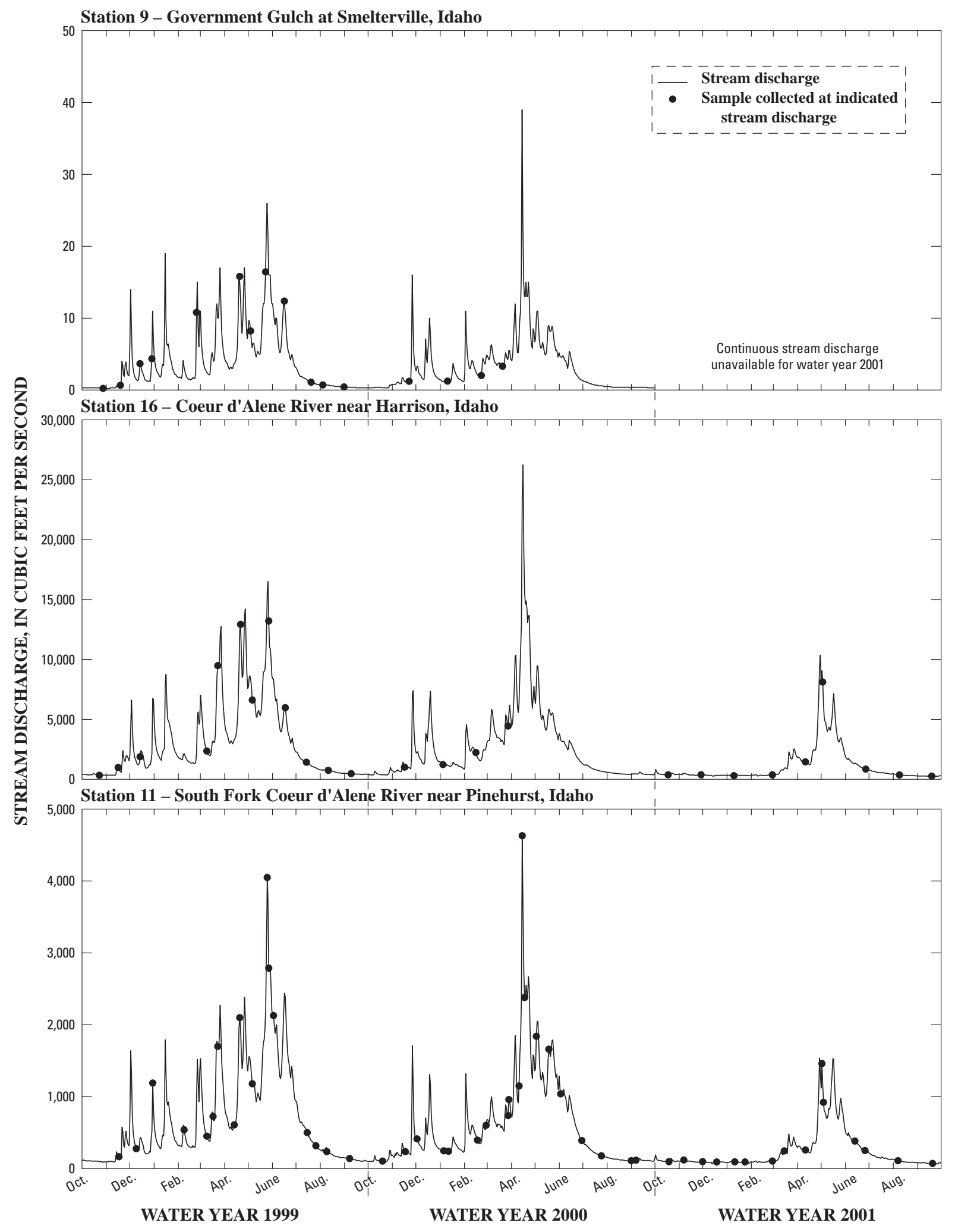

Figure 3. Stream discharge and sample collection dates at three streamflow-gaging stations in the Spokane River Basin, Idaho and Washington, water years 1999-2001. (Locations shown in figures 1 and 2) 
trometry (Fishman, 1993). Quality assurance/quality control procedures used at the NWQL were documented by Pritt and Raese (1995).

\section{Method for Simulating Trace-Metal Loads}

Trace-metal concentrations generally vary in relation to stream discharge. For example, in samples collected during WYs 1999-2001 from the SFCDR near Pinehurst, concentrations of total cadmium and total zinc decreased and concentrations of total lead increased with increasing stream discharge (fig. 4). The relation between concentration and stream discharge noted at Pinehurst typifies many of the mining-affected streams in the CDR Basin (Woods, 2001a). Because of the variability in trace-metal concentration, summary statistics such as a mean station concentration used to characterize a stream might be biased because of variations in sampling frequency and the timing of sampling during the period of data collection. For this analysis, the annual trace-metal load and mean flow-weighted concentrations were simulated for each station. The model used for this analysis is based on the ratingcurve method (Cohn and others, 1989, 1992; Crawford, 1991), which uses regression to estimate constituent loads in relation to stream discharge and time. Similar models have been used to estimate concentration for days when no samples were collected (Gilroy and others, 1990), to estimate the basin flux of nutrients (Goolsby and others, 1999), and to determine trends in water-quality data (Smith and others, 1987). A common form of this type of regression model is:

$$
\begin{aligned}
\ln L=I+a(\ln Q)+b\left(\ln Q^{2}\right)+c(T) \\
+d[\sin (2 \pi T)]+e[\cos (2 \pi T)]+\varepsilon
\end{aligned}
$$

where

$L$ is the constituent load;

$I$ is the regression intercept;

$Q$ is stream discharge;

$T$ is decimal time in years from the beginning of the calibration period;

$a, b, c, d$, and $e$ are regression coefficients that remain constant over time; and

$\varepsilon$ is unaccounted error associated with the regression model.
This regression captures the dependence of concentration on discharge, season (the sine and cosine terms), and any long-term trend. For the load simulations in this report, the $T$ term is equal to $0.0,1.0$, or 2.0, for October 1, 1999, 2000, and 2001, respectively. Because the trace-metal concentrations included censored values (values less than the analytical reporting limit), model coefficients were estimated by the maximum-likelihood method (Dempster and others, 1977; Wolynetz, 1979). In the absence of censored values, the maximum-likelihood method is equivalent to ordinary least-squares regression.

Separate regression models were calibrated for each constituent for each station using some or all of the predictor variables in the regression equation. The best model for each constituent/station combination was selected on the basis of Aikaike Information Criteria (Aikaike, 1981; Judge and others, 1985). The criteria are designed to achieve a good compromise between using as many predictor variables as possible to explain the variance in load while minimizing the standard error of the resulting estimates. Estimates of the logarithms of daily constituent loads for each station were computed using the selected model and daily mean stream discharge. Bias introduced by conversion of the logarithm of load into estimates of load was corrected using the Bradu-Mundlak method (Bradu and Mundlak, 1970; Cohn and others, 1989; Crawford, 1991).

Annual loads were simulated as the sum of the daily loads (computed using the station regression models) for each year. For stations 3, 4, 8, 10, 11, 14, 16,19 , and 20, annual loads were simulated for WYs 1999-2001; for all other stations, annual loads were simulated for WYs 1999-2000. A mean flow-weighted concentration for WYs 1999-2000 was simulated as the total station load during 1999-2000 divided by the total stream discharge at the station during the same time period.

\section{TRACE-METAL OCCURRENCE AND TRANSPORT}

The occurrence and transport of trace metals in the Spokane River Basin are controlled primarily by the metal source and input rate, the tendency of metals to adhere to sediment, and the transport of water and sediment through the basin. Primary sources of trace metals to the SFCDR, CDR, and Spokane Rivers 


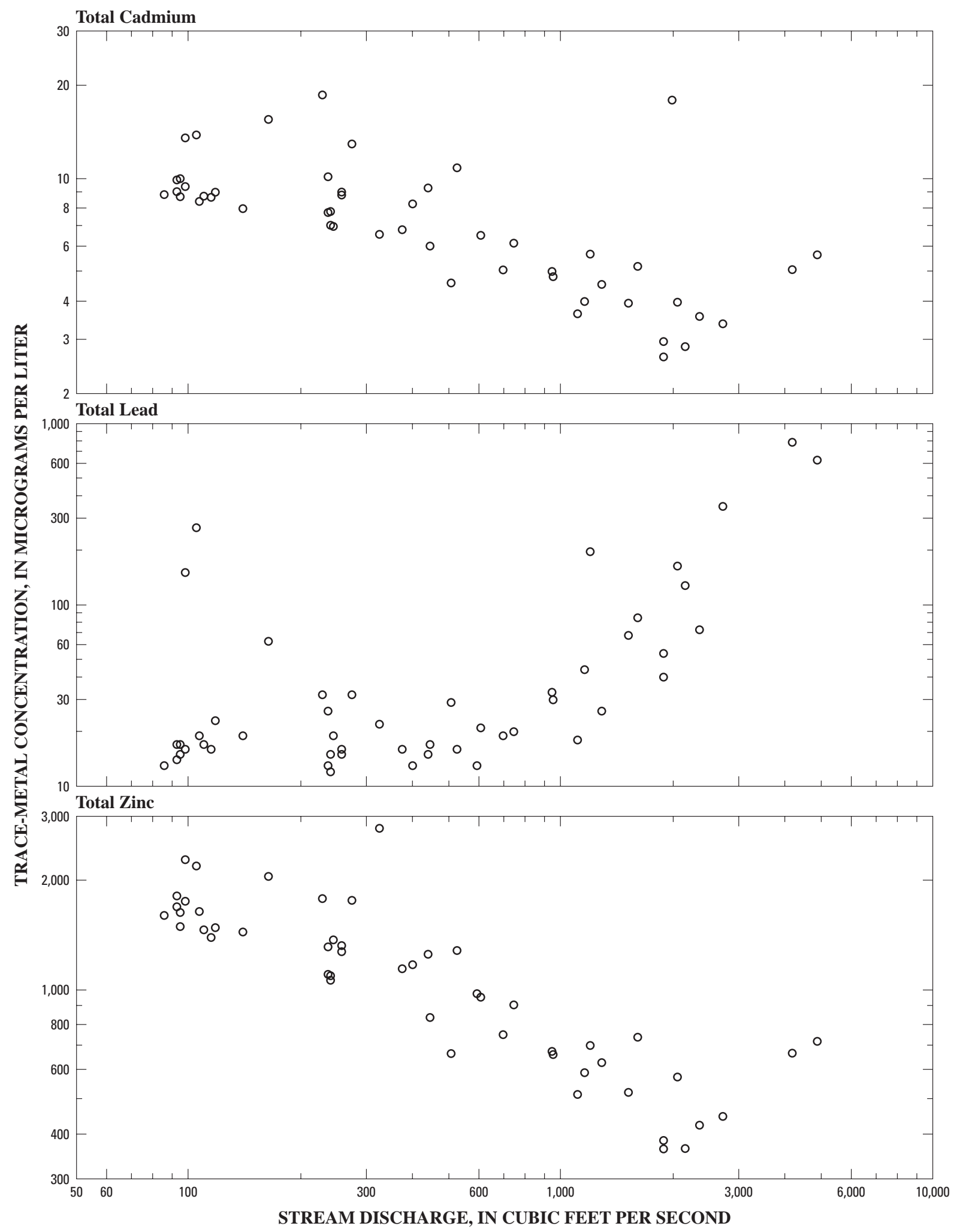

Figure 4. Relation between trace-metal concentrations and stream discharge at streamflow-gaging station 11 on the South Fork Coeur d'Alene River near Pinehurst, Idaho, water years 1999-2001. (Location shown in figures 1 and 2) 
include headwater streams, tributary inflows, groundwater inflow, overland runoff from flood plains, and erosion of streambank and streambed materials. Once trace metals are mobilized in an aquatic system, they can be redistributed within streams and rivers, especially during periods of high stream discharge when transport is at a maximum.

\section{Measured Trace-Metal Concentrations}

Boxplots are useful in illustrating the range and relative concentrations of trace metals in the main-stem and tributary stations in the Spokane River Basin (fig. 5). However, when comparing station concentrations, it is important that boxplots for each station represent similar hydrologic conditions. Although the number of samples collected at each station during WYs 19992001 was variable (table 1), the relative distribution of samples collected at various stream discharges is similar, and the general patterns in concentrations shown in figure 5 are assumed to represent the actual variability.

Concentrations of dissolved and total cadmium, lead, and zinc in samples collected during WYs 19992001 varied widely, both at and among stations (fig. 5). At most of the stations, dissolved cadmium and zinc composed most of the total concentrations. In contrast, dissolved lead generally composed only a small part of the total concentration, often less than 10 percent. A large amount of variability at individual stations was particularly evident in the concentrations of total lead, primarily as a response to changes in stream discharge. Concentrations of cadmium, lead, and zinc also varied widely along the main stem of the SFCDR, the CDR, and the Spokane River. From station 1 on the SFCDR near Mullan downstream to station 6 on the SFCDR at Silverton, concentrations of cadmium, lead, and zinc increased dramatically (fig. 5). At station 6, the concentrations of cadmium, lead, and zinc were generally 1 to 3 orders of magnitude larger than at station 1. Primary sources of trace-metal loading to the 9.3-mi reach between stations 1 and 6 are Canyon and Ninemile Creeks (stations 3 and 4, respectively). Water discharging from these two tributaries contained some of the largest cadmium, lead, and zinc concentrations in the station network (fig. 5). From station 6 downstream to station 11 on the SFCDR near Pinehurst, trace-metal concentrations remained elevated (fig. 5). Sources of trace metals to the SFCDR in the 16-mi reach between stations 6 and 11 include Moon Creek, Government
Gulch, Pine Creek, and ground-water discharge from the shallow alluvial aquifer adjacent to the SFCDR. Median concentrations of total cadmium (190 $\mu \mathrm{g} / \mathrm{L})$ and total zinc $(6,300 \mu \mathrm{g} / \mathrm{L})$ at Government Gulch (station 9) were the largest in the station network. The median concentrations of total cadmium, lead, and zinc at station 11 were $6.7,19$, and $1,100 \mu \mathrm{g} / \mathrm{L}$, respectively (fig. 5).

From station 11 downstream to station 15 on the CDR near Cataldo, the concentrations of cadmium, lead, and zinc decreased as water from the relatively dilute North Fork Coeur d'Alene River (NFCDR) mixed with the metal-enriched water of the SFCDR (fig. 5). From station 15 downstream $32 \mathrm{mi}$ on the CDR to station 16 near Harrison, the median concentrations of dissolved and total cadmium and zinc remained relatively constant, whereas the median concentrations of dissolved and total lead more than doubled (fig. 5). The median concentrations of total cadmium, lead, and zinc at station 16 were $1.7,23$, and $290 \mu \mathrm{g} / \mathrm{L}$, respectively.

The large decrease in the concentrations of cadmium, lead, and zinc between station 16 and station 19 on the Spokane River near Post Falls (fig. 1) indicates dilution and the effectiveness of Coeur d'Alene Lake in trapping trace metals. The median concentrations of total cadmium, lead, and zinc at station 19 were 0.23 , 1.4 , and $64 \mu \mathrm{g} / \mathrm{L}$, respectively (fig. 5). The median concentrations at station 19 represent a decrease from the median concentrations at station 16 of about 86,94 , and 78 percent, respectively. From station 19, $66 \mathrm{mi}$ downstream to station 21 on the Spokane River at Long Lake, the concentrations of dissolved and total cadmium, lead, and zinc generally declined to concentrations similar in magnitude to those in the SFCDR at station 1 (fig. 5). Concentrations of total lead increased slightly between stations 19 and 20 and subsequently decreased between stations 20 and 21. At station 21 (the most downstream station in the station network), the median concentrations of total cadmium, lead, and zinc were $0.085,0.79$, and $35 \mu \mathrm{g} / \mathrm{L}$, respectively.

\section{Simulation of Trace-Metal Concentrations and Loads}

Regression coefficients and coefficients of determination $\left(\mathrm{R}^{2}\right)$ for the best-fit regression model for loads of dissolved and total cadmium, lead, and zinc are presented in table 2. Mean flow-weighted concentrations simulated from the models are presented in 


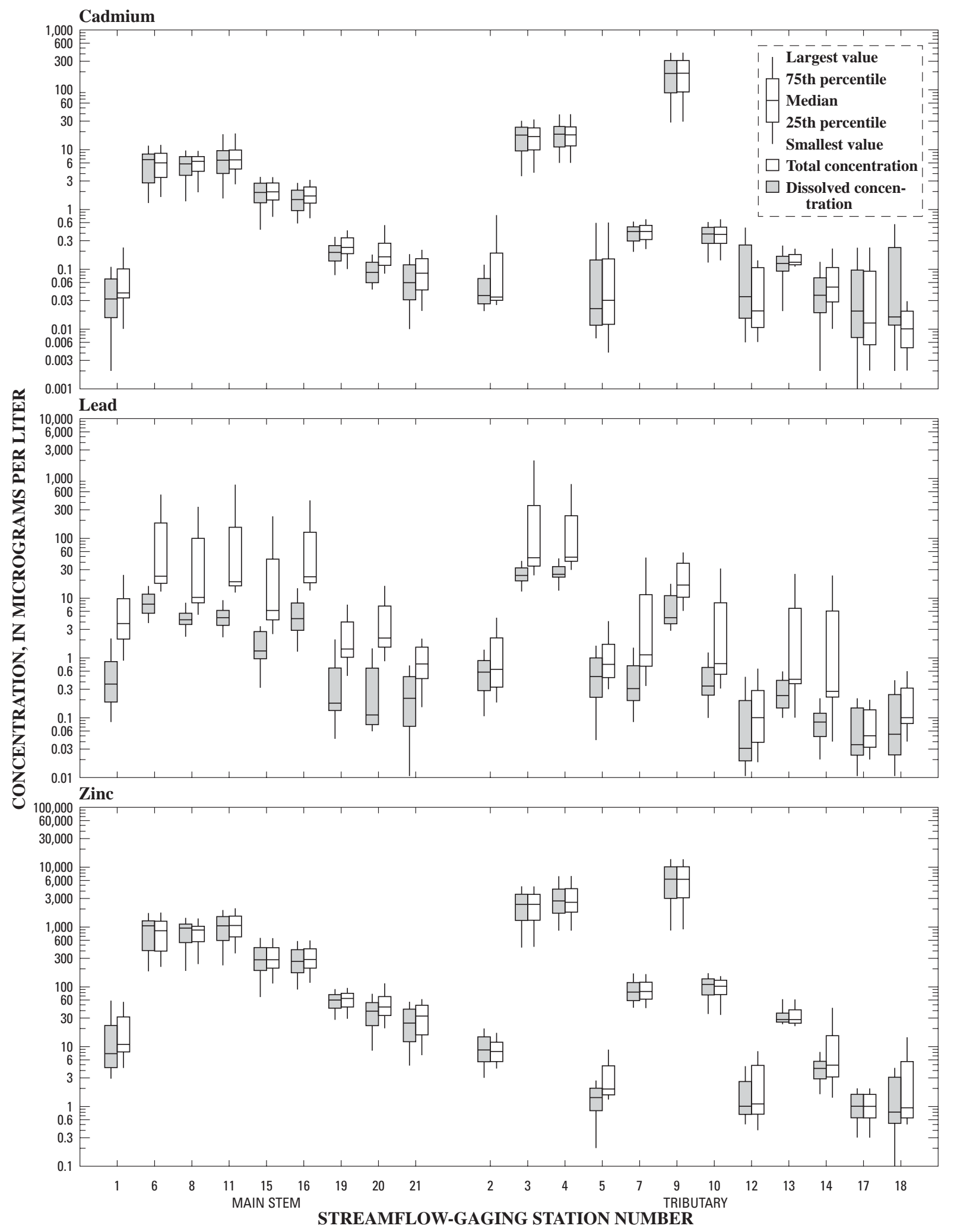

Figure 5. Dissolved and total cadmium, lead, and zinc concentrations in water samples collected at main-stem and tributary streamflow-gaging stations in the Spokane River Basin, Idaho and Washington, water years 1999-2001. (Locations shown in figures 1 and 2) 
Table 2. Regression coefficients and coefficients of determination $\left(R^{2}\right)$ for load models used to simulate dissolved and total cadmium, lead, and zinc loads at streamflow-gaging stations in the Spokane River Basin, Idaho and Washington, water years 1999-2001

[The regression equation is $\ln L=I+a(\ln Q)+b\left(\ln Q^{2}\right)+c(T)+d[\sin (2 \pi T)]+e[\cos (2 \pi T)+\varepsilon$ : where $L$ is the constituent load; $I$ is the regression intercept; $Q$ is stream discharge; $T$ is time in decimal years from the beginning of the calibration period; $a, b, c, d$, and $e$ are regression coefficients; and $\varepsilon$ is the unaccounted error in the model; No., number; USGS, U.S. Geological Survey; $\mathrm{R}^{2}$ represents the amount of variance explained by the model; station locations shown in figures 1 and 2; -, coefficient for indicated term not used in the model; SFCDR, South Fork Coeur d'Alene River; NFCDR, North Fork Coeur d'Alene River; CDR, Coeur d'Alene River; ID, Idaho; WA, Washington]

\begin{tabular}{|c|c|c|c|c|c|c|c|c|}
\hline \multirow[b]{2}{*}{$\begin{array}{c}\text { Station } \\
\text { No. }\end{array}$} & \multirow[b]{2}{*}{ USGS station name } & \multirow[b]{2}{*}{$I$} & \multicolumn{5}{|c|}{ Regression coefficient } & \multirow[b]{2}{*}{$\begin{array}{c}\mathbf{R}^{2} \\
\text { (percent) }\end{array}$} \\
\hline & & & $\mathbf{a}$ & b & c & d & e & \\
\hline \multicolumn{9}{|c|}{ Dissolved cadmium } \\
\hline 1 & SFCDR above Deadman Gulch near Mullan, ID & -5.022 & 2.084 & - & -0.876 & -0.934 & 1.257 & 42 \\
\hline 2 & Canyon Creek near Burke, ID & -6.015 & 1.081 & - & - & -0.399 & 0.476 & 64 \\
\hline 3 & Canyon Creek above mouth at Wallace, ID & 0.905 & 0.926 & -0.152 & - & 0.145 & 0.378 & 78 \\
\hline 4 & Ninemile Creek above mouth at Wallace, ID & -0.091 & 0.742 & - & - & 0.028 & 0.241 & 87 \\
\hline 5 & Placer Creek at Wallace, ID & -3.724 & 1.033 & -0.398 & -1.016 & - & - & 17 \\
\hline 6 & SFCDR at Silverton, ID & 2.379 & 0.570 & -0.130 & -0.439 & 0.346 & 0.215 & 88 \\
\hline 7 & Moon Creek above mouth at Elk Creek, ID & -4.241 & 1.246 & -0.103 & -0.141 & -0.677 & -0.031 & 24 \\
\hline 8 & SFCDR at Elizabeth Park near Kellogg, ID & 1.842 & 0.685 & -0.090 & - & -0.013 & 0.097 & 93 \\
\hline 9 & Government Gulch near mouth at Smelterville, ID & 0.998 & 0.684 & - & - & -0.111 & 0.824 & 68 \\
\hline 10 & Pine Creek below Amy Gulch near Pinehurst, ID & -1.816 & 0.956 & -0.087 & - & 0.010 & 0.282 & 82 \\
\hline 11 & SFCDR near Pinehurst, ID & 2.843 & 0.609 & -0.108 & -0.084 & 0.117 & 0.196 & 92 \\
\hline 12 & NFCDR above Shoshone Creek near Prichard, ID & -0.435 & 0.147 & - & -1.144 & - & - & 13 \\
\hline 13 & Prichard Creek at mouth at Prichard, ID & -2.822 & 0.830 & 0.164 & - & - & - & 89 \\
\hline 14 & NFCDR at Enaville, ID & -2.047 & 0.967 & - & - & - & - & 55 \\
\hline 15 & CDR near Cataldo, ID & 2.988 & 0.421 & - & -0.165 & 0.240 & 0.144 & 92 \\
\hline 16 & CDR near Harrison, ID & 2.932 & 0.913 & -0.142 & -0.140 & -0.215 & 0.174 & 94 \\
\hline 17 & St. Joe River at Calder, ID & -0.768 & 1.572 & - & -1.510 & 0.824 & 1.575 & 51 \\
\hline 18 & St. Maries River near Santa, ID & -3.610 & 1.406 & - & - & 0.205 & 1.186 & 42 \\
\hline 19 & Spokane River near Post Falls, ID & 1.758 & 1.109 & - & -0.094 & 0.235 & 0.116 & 95 \\
\hline 20 & Spokane River at 7-Mile Bridge, WA & 1.001 & 1.529 & - & - & - & - & 98 \\
\hline 21 & Spokane River at Long Lake, WA & 0.935 & 1.565 & - & - & 0.665 & -0.085 & 90 \\
\hline \multicolumn{9}{|c|}{ Total cadmium } \\
\hline 1 & SFCDR above Deadman Gulch near Mullan, ID & -5.207 & 1.106 & - & - & - & - & 76 \\
\hline 2 & Canyon Creek near Burke, ID & -6.206 & 0.771 & 0.223 & - & - & - & 66 \\
\hline 3 & Canyon Creek above mouth at Wallace, ID & 0.856 & 0.941 & -0.115 & - & 0.164 & 0.363 & 67 \\
\hline 4 & Ninemile Creek above mouth at Wallace, ID & 0.081 & 0.808 & - & - & 0.019 & 0.244 & 87 \\
\hline 5 & Placer Creek at Wallace, ID & -3.255 & 0.924 & - & -1.726 & - & - & 7 \\
\hline 6 & SFCDR at Silverton, ID & 2.113 & 0.605 & - & -0.308 & 0.282 & 0.256 & 82 \\
\hline 7 & Moon Creek above mouth at Elk Creek, ID & -4.552 & 1.290 & - & - & -0.793 & -0.039 & 20 \\
\hline 8 & SFCDR at Elizabeth Park near Kellogg, ID & 1.955 & 0.682 & - & -0.070 & - & - & 83 \\
\hline
\end{tabular}


Table 2. Regression coefficients and coefficients of determination $\left(R^{2}\right)$ for load models used to simulate dissolved and total cadmium, lead, and zinc loads at streamflow-gaging stations in the Spokane River Basin, Idaho and Washington, water years 1999-2001-Continued

\begin{tabular}{|c|c|c|c|c|c|c|c|c|}
\hline \multirow[b]{2}{*}{$\begin{array}{c}\text { Station } \\
\text { No. }\end{array}$} & \multirow[b]{2}{*}{ USGS station name } & \multirow[b]{2}{*}{ I } & \multicolumn{5}{|c|}{ Regression coefficient } & \multirow[b]{2}{*}{$\begin{array}{c}\mathbf{R}^{2} \\
\text { (percent) }\end{array}$} \\
\hline & & & a & b & c & d & e & \\
\hline \multicolumn{9}{|c|}{ Total cadmium -Continued } \\
\hline 9 & Government Gulch near mouth at Smelterville, ID & 1.012 & 0.712 & - & - & -0.133 & 0.797 & 67 \\
\hline 10 & Pine Creek below Amy Gulch near Pinehurst, ID & -1.738 & 0.833 & - & -0.130 & 0.159 & 0.275 & 72 \\
\hline 11 & SFCDR near Pinehurst, ID & 2.851 & 0.690 & - & -0.110 & 0.087 & 0.168 & 82 \\
\hline 12 & NFCDR above Shoshone Creek near Prichard, ID & -0.881 & -0.981 & 0.652 & -2.256 & 2.385 & 1.078 & 99 \\
\hline 13 & Prichard Creek at mouth at Prichard, ID & -2.360 & 1.035 & 0.081 & -0.131 & - & - & 99 \\
\hline 14 & NFCDR at Enaville, ID & -1.910 & 1.323 & - & - & - & - & 81 \\
\hline 15 & CDR near Cataldo, ID & 2.760 & 0.809 & 0.130 & - & -0.080 & 0.241 & 96 \\
\hline 16 & CDR near Harrison, ID & 2.965 & 0.843 & - & -0.208 & - & - & 89 \\
\hline 17 & St. Joe River at Calder, ID & -0.773 & 0.495 & - & -1.261 & 1.063 & 0.844 & 52 \\
\hline 18 & St. Maries River near Santa, ID & -4.625 & 0.875 & - & - & - & - & 39 \\
\hline 19 & Spokane River near Post Falls, ID & 2.007 & 1.140 & - & -0.105 & 0.211 & 0.112 & 96 \\
\hline 20 & Spokane River at 7-Mile Bridge, WA & 1.305 & 1.393 & 0.174 & - & - & - & 96 \\
\hline 21 & Spokane River at Long Lake, WA & 1.215 & 1.047 & -0.373 & - & 0.982 & -0.200 & 96 \\
\hline \multicolumn{9}{|c|}{ Dissolved lead } \\
\hline 1 & SFCDR above Deadman Gulch near Mullan, ID & -3.648 & 1.714 & - & - & -0.618 & 1.285 & 74 \\
\hline 2 & Canyon Creek near Burke, ID & -3.660 & 1.079 & - & - & - & - & 50 \\
\hline 3 & Canyon Creek above mouth at Wallace, ID & 1.673 & 0.873 & - & -0.234 & - & - & 88 \\
\hline 4 & Ninemile Creek above mouth at Wallace, ID & 0.789 & 1.002 & -0.101 & -0.163 & - & - & 89 \\
\hline 5 & Placer Creek at Wallace, ID & -2.625 & 0.501 & -0.190 & - & - & - & 29 \\
\hline 6 & SFCDR at Silverton, ID & 2.001 & 0.630 & - & - & -0.011 & -0.249 & 93 \\
\hline 7 & Moon Creek above mouth at Elk Creek, ID & -3.118 & -0.075 & - & -1.135 & 1.656 & 0.652 & 73 \\
\hline 8 & SFCDR at Elizabeth Park near Kellogg, ID & 1.850 & 0.787 & - & -0.177 & -0.022 & -0.254 & 98 \\
\hline 9 & Government Gulch near mouth at Smelterville, ID & -2.013 & 1.114 & -0.467 & - & 0.437 & 0.427 & 60 \\
\hline 10 & Pine Creek below Amy Gulch near Pinehurst, ID & -2.319 & 1.083 & 0.096 & - & - & - & 90 \\
\hline 11 & SFCDR near Pinehurst, ID & 2.429 & 0.644 & 0.063 & -0.151 & 0.108 & -0.383 & 94 \\
\hline 12 & NFCDR above Shoshone Creek near Prichard, ID & -2.443 & 0.996 & - & - & - & - & 8 \\
\hline 13 & Prichard Creek at mouth at Prichard, ID & -0.490 & 1.276 & - & -0.919 & - & - & 97 \\
\hline 14 & NFCDR at Enaville, ID & -1.444 & 1.048 & 0.164 & - & - & - & 93 \\
\hline 15 & CDR near Cataldo, ID & 3.063 & 0.425 & 0.170 & -0.435 & 0.689 & -0.796 & 94 \\
\hline 16 & CDR near Harrison, ID & 3.606 & 1.217 & - & - & - & - & 87 \\
\hline 17 & St. Joe River at Calder, ID & 0.596 & -0.131 & 0.289 & -1.373 & 1.230 & 0.143 & 74 \\
\hline 18 & St. Maries River near Santa, ID & -2.796 & 1.494 & - & - & - & - & 73 \\
\hline
\end{tabular}


Table 2. Regression coefficients and coefficients of determination $\left(R^{2}\right)$ for load models used to simulate dissolved and total cadmium, lead, and zinc loads at streamflow-gaging stations in the Spokane River Basin, Idaho and Washington, water years 1999-2001-Continued

\begin{tabular}{|c|c|c|c|c|c|c|c|c|}
\hline \multirow[b]{2}{*}{$\begin{array}{c}\text { Station } \\
\text { No. }\end{array}$} & \multirow[b]{2}{*}{ USGS station name } & \multirow[b]{2}{*}{ I } & \multicolumn{5}{|c|}{ Regression coefficient } & \multirow[b]{2}{*}{$\begin{array}{c}\mathbf{R}^{2} \\
\text { (percent) }\end{array}$} \\
\hline & & & a & b & c & d & $\mathbf{e}$ & \\
\hline \multicolumn{9}{|c|}{ Dissolved lead -Continued } \\
\hline 19 & Spokane River near Post Falls, ID & 1.354 & 1.506 & 0.242 & - & - & - & 82 \\
\hline 20 & Spokane River at 7-Mile Bridge, WA & 1.000 & 1.661 & 0.470 & - & - & - & 98 \\
\hline 21 & Spokane River at Long Lake, WA & 3.181 & 2.772 & - & -0.864 & - & - & 67 \\
\hline \multicolumn{9}{|c|}{ Total lead } \\
\hline 1 & SFCDR above Deadman Gulch near Mullan, ID & -1.241 & 1.672 & - & - & 0.070 & 1.065 & 85 \\
\hline 2 & Canyon Creek near Burke, ID & -4.720 & 0.899 & 0.297 & 0.668 & - & - & 93 \\
\hline 3 & Canyon Creek above mouth at Wallace, ID & 2.290 & 1.172 & 0.258 & -0.279 & - & - & 61 \\
\hline 4 & Ninemile Creek above mouth at Wallace, ID & 1.072 & 1.429 & 0.219 & - & - & - & 92 \\
\hline 5 & Placer Creek at Wallace, ID & -3.581 & 0.990 & 0.276 & 0.617 & - & - & 94 \\
\hline 6 & SFCDR at Silverton, ID & 2.617 & 1.065 & 0.483 & - & - & - & 91 \\
\hline 7 & Moon Creek above mouth at Elk Creek, ID & -3.883 & 1.782 & 0.348 & - & -1.177 & 0.539 & 31 \\
\hline 8 & SFCDR at Elizabeth Park near Kellogg, ID & 2.745 & 1.375 & 0.358 & -0.230 & - & - & 92 \\
\hline 9 & Government Gulch near mouth at Smelterville, ID & -1.272 & 1.530 & - & - & 0.128 & 0.404 & 75 \\
\hline 10 & Pine Creek below Amy Gulch near Pinehurst, ID & -1.878 & 1.387 & 0.244 & - & - & - & 89 \\
\hline 11 & SFCDR near Pinehurst, ID & 4.260 & 1.321 & 0.426 & -0.352 & - & - & 98 \\
\hline 12 & NFCDR above Shoshone Creek near Prichard, ID & -2.226 & 1.164 & 0.312 & - & - & - & 92 \\
\hline 13 & Prichard Creek at mouth at Prichard, ID & -1.346 & 1.661 & 0.349 & - & - & - & 89 \\
\hline 14 & NFCDR at Enaville, ID & 0.131 & 1.333 & 0.564 & -0.391 & - & - & 98 \\
\hline 15 & CDR near Cataldo, ID & 4.217 & 2.050 & 0.250 & - & -0.782 & -0.194 & 98 \\
\hline 16 & CDR near Harrison, ID & 4.985 & 1.346 & 0.303 & - & - & - & 93 \\
\hline 17 & St. Joe River at Calder, ID & 0.981 & 1.080 & - & -1.491 & 0.311 & 0.386 & 75 \\
\hline 18 & St. Maries River near Santa, ID & -1.171 & 3.023 & -0.519 & - & -2.287 & 0.600 & 84 \\
\hline 19 & Spokane River near Post Falls, ID & 3.292 & 1.686 & 0.215 & - & -0.237 & -0.354 & 93 \\
\hline 20 & Spokane River at 7-Mile Bridge, WA & 3.092 & 1.702 & 0.573 & - & - & - & 99 \\
\hline 21 & Spokane River at Long Lake, WA & 3.457 & 2.146 & - & - & - & - & 90 \\
\hline \multicolumn{9}{|c|}{ Dissolved zinc } \\
\hline 1 & SFCDR above Deadman Gulch near Mullan, ID & 0.890 & 0.939 & - & -0.570 & -0.082 & 0.809 & 75 \\
\hline 2 & Canyon Creek near Burke, ID & -0.140 & 1.262 & -0.118 & -0.346 & 0.114 & 0.582 & 73 \\
\hline 3 & Canyon Creek above mouth at Wallace, ID & 5.854 & 0.915 & -0.170 & - & 0.217 & 0.414 & 81 \\
\hline 4 & Ninemile Creek above mouth at Wallace, ID & 4.976 & 0.746 & - & - & 0.031 & 0.300 & 84 \\
\hline 5 & Placer Creek at Wallace, ID & -1.665 & 0.801 & - & - & - & - & 58 \\
\hline 6 & SFCDR at Silverton, ID & 7.444 & 0.478 & -0.129 & -0.311 & 0.340 & 0.292 & 83 \\
\hline 7 & Moon Creek above mouth at Elk Creek, ID & 1.271 & 1.271 & -0.112 & -0.254 & -0.727 & 0.103 & 26 \\
\hline 8 & SFCDR at Elizabeth Park near Kellogg, ID & 6.824 & 0.685 & -0.102 & - & 0.054 & 0.124 & 87 \\
\hline
\end{tabular}


Table 2. Regression coefficients and coefficients of determination $\left(R^{2}\right)$ for load models used to simulate dissolved and total cadmium, lead, and zinc loads at streamflow-gaging stations in the Spokane River Basin, Idaho and Washington, water years 1999-2001-Continued

\begin{tabular}{|c|c|c|c|c|c|c|c|c|}
\hline \multirow[b]{2}{*}{$\begin{array}{c}\text { Station } \\
\text { No. }\end{array}$} & \multirow[b]{2}{*}{ USGS station name } & \multirow[b]{2}{*}{$I$} & \multicolumn{5}{|c|}{ Regression coefficient } & \multirow[b]{2}{*}{$\begin{array}{c}\mathbf{R}^{2} \\
\text { (percent) }\end{array}$} \\
\hline & & & a & b & c & d & e & \\
\hline \multicolumn{9}{|c|}{ Dissolved zinc -Continued } \\
\hline 9 & Government Gulch near mouth at Smelterville, ID & 4.495 & 0.679 & - & - & -0.107 & 0.829 & 69 \\
\hline 10 & Pine Creek below Amy Gulch near Pinehurst, ID & 3.929 & 0.731 & - & -0.152 & 0.325 & 0.275 & 77 \\
\hline 11 & SFCDR near Pinehurst, ID & 7.783 & 0.562 & -0.075 & -0.061 & 0.043 & 0.175 & 92 \\
\hline 12 & NFCDR above Shoshone Creek near Prichard, ID & 1.099 & 1.460 & -0.274 & - & - & - & 54 \\
\hline 13 & Prichard Creek at mouth at Prichard, ID & 3.063 & 0.822 & 0.083 & -0.173 & 0.235 & 0.066 & 98 \\
\hline 14 & NFCDR at Enaville, ID & 3.095 & 1.241 & -0.078 & - & - & - & 95 \\
\hline 15 & CDR near Cataldo, ID & 8.055 & 0.376 & - & -0.180 & 0.193 & 0.096 & 95 \\
\hline 16 & CDR near Harrison, ID & 8.092 & 0.657 & -0.120 & -0.130 & 0.078 & 0.225 & 97 \\
\hline 17 & St. Joe River at Calder, ID & 1.604 & 1.174 & - & - & - & - & 75 \\
\hline 18 & St. Maries River near Santa, ID & -0.003 & 1.548 & - & - & - & - & 77 \\
\hline 19 & Spokane River near Post Falls, ID & 7.383 & 1.047 & - & -0.083 & 0.271 & 0.247 & 98 \\
\hline 20 & Spokane River at 7-Mile Bridge, WA & 6.927 & 1.515 & -0.115 & - & 0.023 & 0.276 & 97 \\
\hline 21 & Spokane River at Long Lake, WA & 6.702 & 1.195 & - & - & 0.943 & 0.169 & 92 \\
\hline \multicolumn{9}{|c|}{ Total zinc } \\
\hline 1 & SFCDR above Deadman Gulch near Mullan, ID & 1.269 & 1.118 & - & -0.584 & 0.338 & 0.808 & 82 \\
\hline 2 & Canyon Creek near Burke, ID & 0.058 & 1.033 & - & -0.510 & 0.299 & 0.387 & 93 \\
\hline 3 & Canyon Creek above mouth at Wallace, ID & 5.852 & 0.916 & -0.163 & - & 0.218 & 0.422 & 82 \\
\hline 4 & Ninemile Creek above mouth at Wallace, ID & 5.107 & 0.800 & - & - & 0.030 & 0.331 & 88 \\
\hline 5 & Placer Creek at Wallace, ID & -1.574 & 0.978 & 0.294 & - & - & - & 95 \\
\hline 6 & SFCDR at Silverton, ID & 7.421 & 0.476 & -0.121 & -0.299 & 0.350 & 0.289 & 85 \\
\hline 7 & Moon Creek above mouth at Elk Creek, ID & 1.194 & 1.078 & - & -0.279 & -0.433 & 0.160 & 37 \\
\hline 8 & SFCDR at Elizabeth Park near Kellogg, ID & 6.714 & 0.741 & - & - & 0.057 & 0.150 & 83 \\
\hline 9 & Government Gulch near mouth at Smelterville, ID & 4.516 & 0.694 & - & - & -0.123 & 0.791 & 66 \\
\hline 10 & Pine Creek below Amy Gulch near Pinehurst, ID & 3.578 & 0.866 & - & - & 0.198 & 0.269 & 80 \\
\hline 11 & SFCDR near Pinehurst, ID & 7.848 & 0.642 & - & -0.092 & 0.012 & 0.179 & 81 \\
\hline 12 & NFCDR above Shoshone Creek near Prichard, ID & 0.923 & 0.702 & - & - & 1.307 & 0.019 & 79 \\
\hline 13 & Prichard Creek at mouth at Prichard, ID & 3.172 & 0.853 & 0.123 & -0.241 & 0.325 & 0.056 & 99 \\
\hline 14 & NFCDR at Enaville, ID & 3.220 & 1.473 & - & - & - & - & 89 \\
\hline 15 & CDR near Cataldo, ID & 7.970 & 0.591 & 0.127 & -0.154 & 0.080 & 0.154 & 96 \\
\hline 16 & CDR near Harrison, ID & 7.953 & 0.776 & - & -0.139 & -0.005 & 0.208 & 88 \\
\hline 17 & St. Joe River at Calder, ID & 1.604 & 1.178 & - & - & - & - & 76 \\
\hline 18 & St. Maries River near Santa, ID & 0.294 & 1.339 & - & - & - & - & 37 \\
\hline 19 & Spokane River near Post Falls, ID & 7.300 & 1.101 & - & - & 0.249 & 0.195 & 98 \\
\hline 20 & Spokane River at 7-Mile Bridge, WA & 7.039 & 1.382 & - & - & - & - & 92 \\
\hline 21 & Spokane River at Long Lake, WA & 6.926 & 1.287 & - & - & 0.875 & 0.188 & 94 \\
\hline
\end{tabular}


table 3. For the 21 stations in table 3, the median ratios of the dissolved to total concentrations of cadmium, lead, and zinc were 87, 14, and 92 percent, respectively.
The relatively large $\mathrm{R}^{2}$ values for the models (table 2) indicate that, at most of the stations, the models successfully simulated the variability in trace-metal

Table 3. Simulated mean flow-weighted concentrations of cadmium, lead, and zinc at streamflow-gaging stations in the Spokane River Basin, Idaho and Washington, water years 1999-2000

[Station locations shown in figures 1 and 2; No., number; USGS, U.S. Geological Survey; SFCDR, South Fork Coeur d'Alene River; CDR, Coeur d'Alene River; ID, Idaho; NFCDR, North Fork Coeur d'Alene River; WA, Washington]

\begin{tabular}{|c|c|c|c|c|c|c|c|}
\hline \multirow[b]{2}{*}{$\begin{array}{l}\text { Station } \\
\text { No. }\end{array}$} & \multirow[b]{2}{*}{ USGS station name } & \multicolumn{6}{|c|}{$\begin{array}{l}\text { Simulated mean flow-weighted concentration } \\
\text { (micrograms per liter) }\end{array}$} \\
\hline & & $\begin{array}{l}\text { Dissolved } \\
\text { cadmium }\end{array}$ & $\begin{array}{c}\text { Total } \\
\text { cadmium }\end{array}$ & $\begin{array}{l}\text { Dissolved } \\
\text { lead }\end{array}$ & $\begin{array}{l}\text { Total } \\
\text { lead }\end{array}$ & $\begin{array}{l}\text { Dissolved } \\
\text { zinc }\end{array}$ & $\begin{array}{l}\text { Total } \\
\text { zinc }\end{array}$ \\
\hline \multicolumn{8}{|c|}{ Main-stem stations } \\
\hline 1 & SFCDR above Deadman Gulch near Mullan, ID & 0.03 & 0.06 & 0.33 & 4.7 & 7.1 & 13 \\
\hline 6 & SFCDR at Silverton, ID & 4.3 & 4.7 & 7.2 & 64 & 640 & 650 \\
\hline 8 & SFCDR at Elizabeth Park near Kellogg, ID & 3.9 & 4.5 & 3.9 & 58 & 570 & 620 \\
\hline 11 & SFCDR near Pinehurst, ID & 4.9 & 5.7 & 4.0 & 80 & 700 & 810 \\
\hline 15 & CDR near Cataldo, ID & 1.1 & 1.6 & 1.5 & 37 & 160 & 210 \\
\hline 16 & CDR near Harrison, ID & 1.2 & 1.6 & 6.2 & 88 & 200 & 240 \\
\hline 19 & Spokane River near Post Falls, ID & 0.25 & 0.32 & 0.43 & 3.1 & 68 & 71 \\
\hline 20 & Spokane River at 7-Mile Bridge, WA & 0.17 & 0.24 & 0.41 & 4.0 & 52 & 60 \\
\hline 21 & Spokane River at Long Lake, WA & 0.12 & 0.11 & 0.41 & 1.3 & 34 & 42 \\
\hline \multicolumn{8}{|c|}{ Tributary stations } \\
\hline 2 & Canyon Creek near Burke, ID & 0.04 & 0.07 & 0.59 & 1.7 & 6.8 & 7.4 \\
\hline 3 & Canyon Creek above mouth at Wallace, ID & 12 & 13 & 23 & 165 & 1,700 & 1,700 \\
\hline 4 & Ninemile Creek above mouth at Wallace, ID & 14 & 14 & 26 & 140 & 2,200 & 2,300 \\
\hline 5 & Placer Creek at Wallace, ID & 0.03 & 0.03 & 0.35 & 1.2 & 1.4 & 3.0 \\
\hline 7 & Moon Creek above mouth at Elk Creek, ID & 0.35 & 0.41 & 0.31 & 2.9 & 69 & 69 \\
\hline 9 & Government Gulch near mouth at Smelterville, ID & 150 & 150 & 6.8 & 26 & 4,900 & 5,000 \\
\hline 10 & Pine Creek below Amy Gulch near Pinehurst, ID & 0.34 & 0.34 & 0.51 & 3.3 & 89 & 93 \\
\hline 12 & NFCDR above Shoshone Creek near Prichard, ID & 0.04 & 0.02 & 0.07 & 0.25 & 1.5 & 2.4 \\
\hline 13 & Prichard Creek at mouth at Prichard, ID & 0.13 & 0.15 & 0.29 & 5.6 & 28 & 32 \\
\hline 14 & NFCDR at Enaville, ID & 0.04 & 0.05 & 0.09 & 2.0 & 5.1 & 11 \\
\hline 17 & St. Joe River at Calder, ID & 0.03 & 0.02 & 0.03 & 0.05 & 1.3 & 1.3 \\
\hline 18 & St. Maries River near Santa, ID & 0.07 & 0.01 & 0.22 & 0.49 & 2.7 & 2.5 \\
\hline
\end{tabular}


loads. The median $\mathrm{R}^{2}$ of the load models for all 21 stations was largest for total lead (92 percent), and smallest for dissolved and total cadmium (82 percent). In 16 of the load models for total lead, the $\ln Q^{2}$ term was significant with a positive coefficient (table 2), indicative of concentrations that increase dramatically with increased stream discharge. In contrast, in 10 of the load models for dissolved zinc, the $\ln Q^{2}$ term was significant with a negative coefficient indicative of concentrations that decrease dramatically with increased stream discharge. The influence of stream discharge on the concentrations of total lead and dissolved zinc at station 11 is illustrated in figure 6 . The measured concentrations in figure 6 represent samples collected onsite; the simulated concentrations represent values from the load models in table 2. During all 3 years of sampling, the measured and simulated annual peak concentrations of total lead coincided with the annual peak stream discharge (fig. 6). During 1999-2001, the peaks occurred during the spring snowmelt runoff. Conversely, the measured and simulated concentrations of dissolved zinc were smallest during the annual peak stream discharge.

In general, the load models for stations where trace-metal concentrations were relatively large were better at simulating the actual loads than were models for stations where concentrations were near the analytical reporting limit. At the eight stations where flowweighted concentrations of trace metals were largest (stations 3, 4, 6, 8, 9, 11, 15, and 16), the median $\mathrm{R}^{2}$ values of the load models were $90,82,91,92,86$, and 84 percent for dissolved and total cadmium, lead, and zinc, respectively. At the seven stations where flowweighted concentrations were smallest (stations 1, 2, 5, $12,14,17$, and 18 ), the median $\mathrm{R}^{2}$ values were 47,59 , $62,93,74$, and 84 percent for dissolved and total cadmium, lead, and zinc, respectively. The lower $\mathrm{R}^{2}$ values at these seven stations probably were attributable to a larger number of censored data values and, thus, less confidence in the analytical results.

Relations between measured and simulated loads of total cadmium, lead, and zinc at four stations are shown in figures 7,8 , and 9, respectively. Although the measured and simulated loads of total cadmium, lead, and zinc compare favorably during most of the 3 years of sampling, a hysteresis effect on trace-metal loads is evident during snowmelt runoff. Hysteresis is a result of differences in trace-metal concentrations for a given stream discharge over the ascending and descending limbs of the stream hydrograph. As stream discharge is rising, materials stored within the stream channel or in terrestrial zones become mobile as they are subjected to increased stream velocities. Samples collected during the ascending limb and near the peak of the stream hydrograph typically contain larger concentrations of sediment and sediment-associated trace metals than samples collected during the descending limb. The magnitude of the hysteresis effect can be affected by antecedent conditions and by the magnitude of the stream discharge generating hysteresis. Clark and Woods (2001) and Woods (2001a) documented the hysteresis effect on sediment and trace-metal concentrations at numerous stations in the SFCDR. Measured sediment and sediment-associated trace-metal concentrations were between 1.5 and 3.6 times larger on the ascending limb of the snowmelt runoff hydrograph than on the descending limb at nearly equal discharge. In contrast, dissolved trace-metal concentrations showed minimal effect from hysteresis (Woods, 2001a).

Because the load models developed in this study do not account for hysteresis, errors in the load simulations may occur during short time periods (daily or weekly) when the stream discharge is changing rapidly. Hysteresis is particularly evident at station 11 on the SFCDR near Pinehurst (figs. 7, 8, and 9). On April 14, 2000, the mean stream discharge at station 11 peaked at $4,630 \mathrm{ft}^{3} / \mathrm{s}$ and the measured loads of total cadmium, lead, and zinc on that day were $150,17,000$, and $19,000 \mathrm{lb}$, respectively. The simulated loads of total cadmium, lead, and zinc on April 14 were 81, 13,000, and $10,000 \mathrm{lb}$, respectively, or underestimates of the measured loads by 46, 24, and 47 percent, respectively. Three days later on April 17, the daily mean stream discharge at station 11 had decreased to $2,380 \mathrm{ft}^{3} / \mathrm{s}$ and the measured loads of total cadmium, lead, and zinc were 45, 930, and 5,400 lb, respectively. The simulated loads on April 17 of total cadmium, lead, and zinc were 51, 1,600 , and $6,600 \mathrm{lb}$, respectively, or overestimates of the measured loads by 13,72 , and 22 percent, respectively. Thus, during short periods of time, significant errors in the load simulations may result from hysteresis. However, over periods of longer duration (monthly or annually), the errors associated with hysteresis would probably balance out and the overall resultant error in the estimates of total loads would be minimized. 


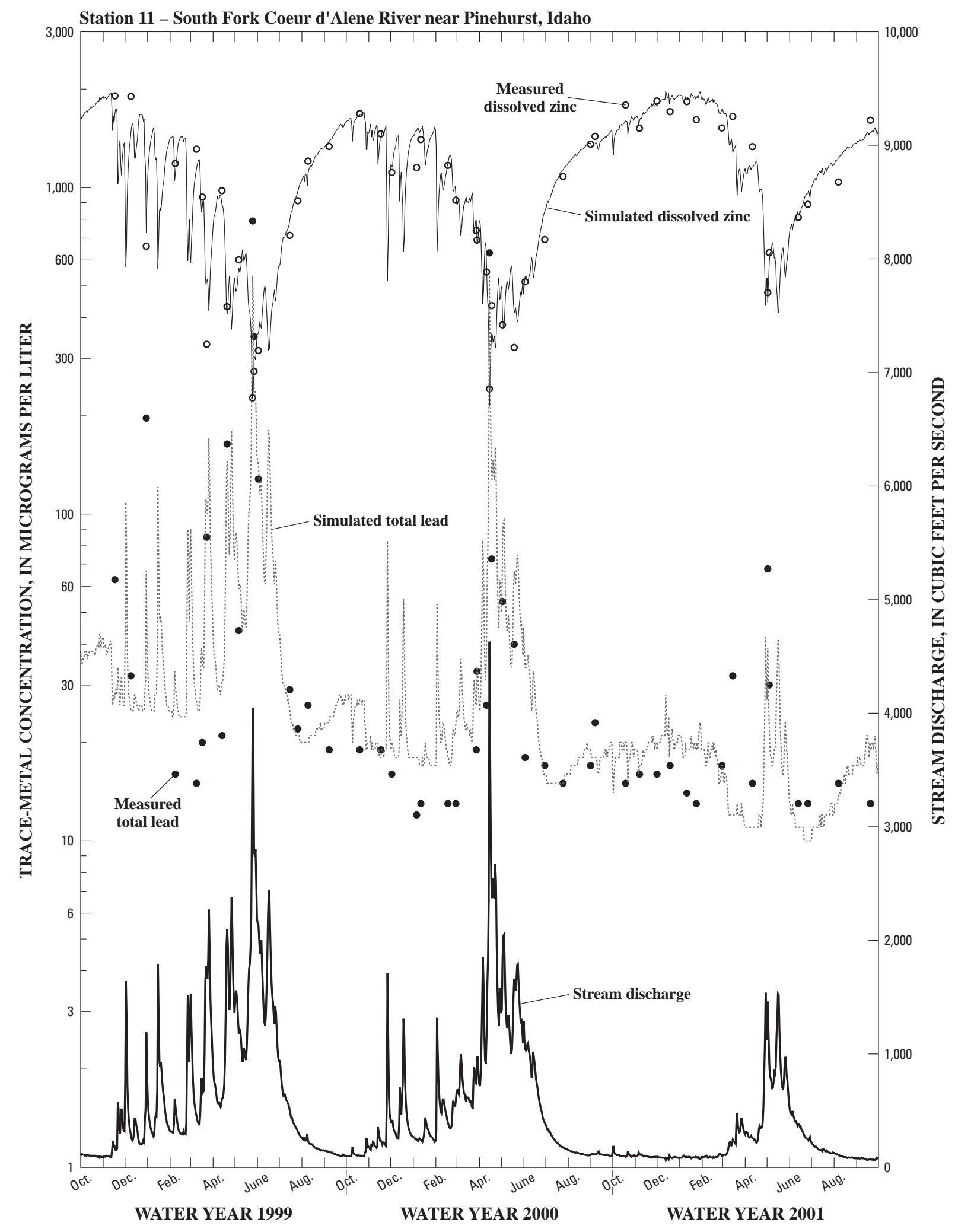

Figure 6. Stream discharge and measured and simulated concentrations of total lead and dissolved zinc at streamflow-gaging station 11 on the South Fork Coeur d'Alene River near Pinehurst, Idaho, water years 1999-2001. (Location shown in figure 2) 
Station 3 - Canyon Creek at Wallace, Idaho

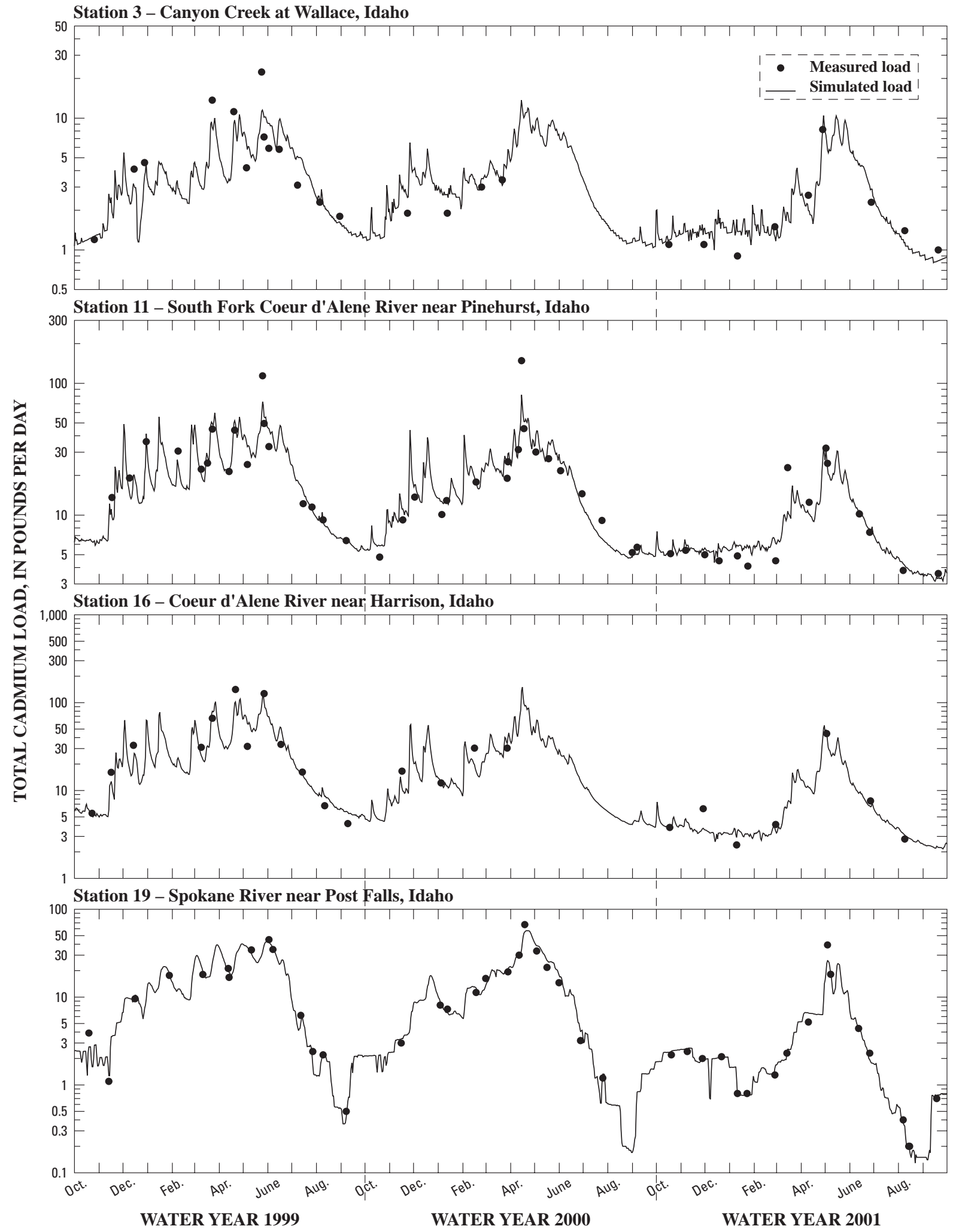

Figure 7. Measured and simulated loads of total cadmium at four streamflow-gaging stations in the Spokane River Basin, Idaho and Washington, water years 1999-2001. (Locations shown in figures 1 and 2) 
Station 3 - Canyon Creek at Wallace, Idaho
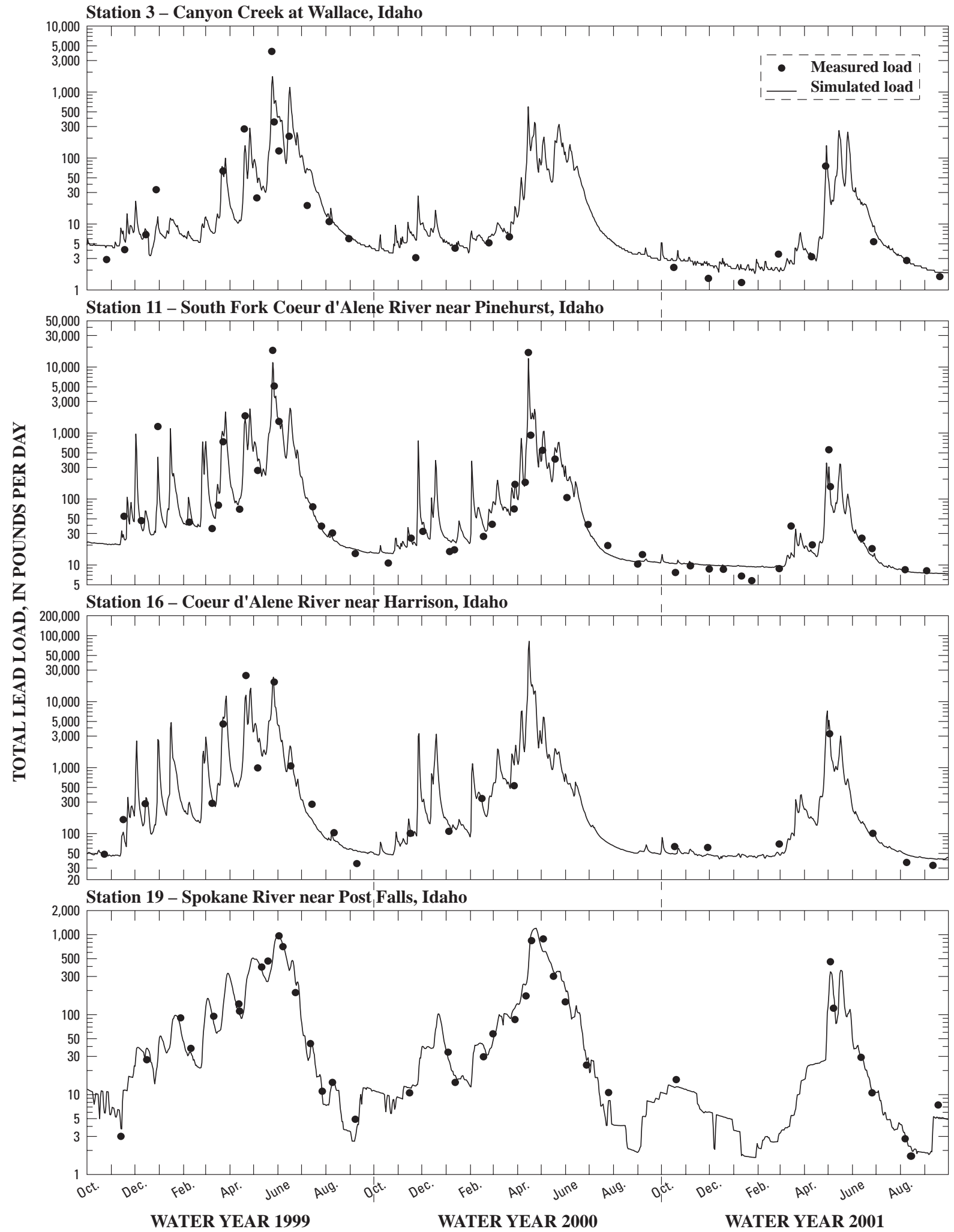

Figure 8. Measured and simulated loads of total lead at four streamflow-gaging stations in the Spokane River Basin, Idaho and Washington, water years 1999-2001. (Locations shown in figures 1 and 2) 


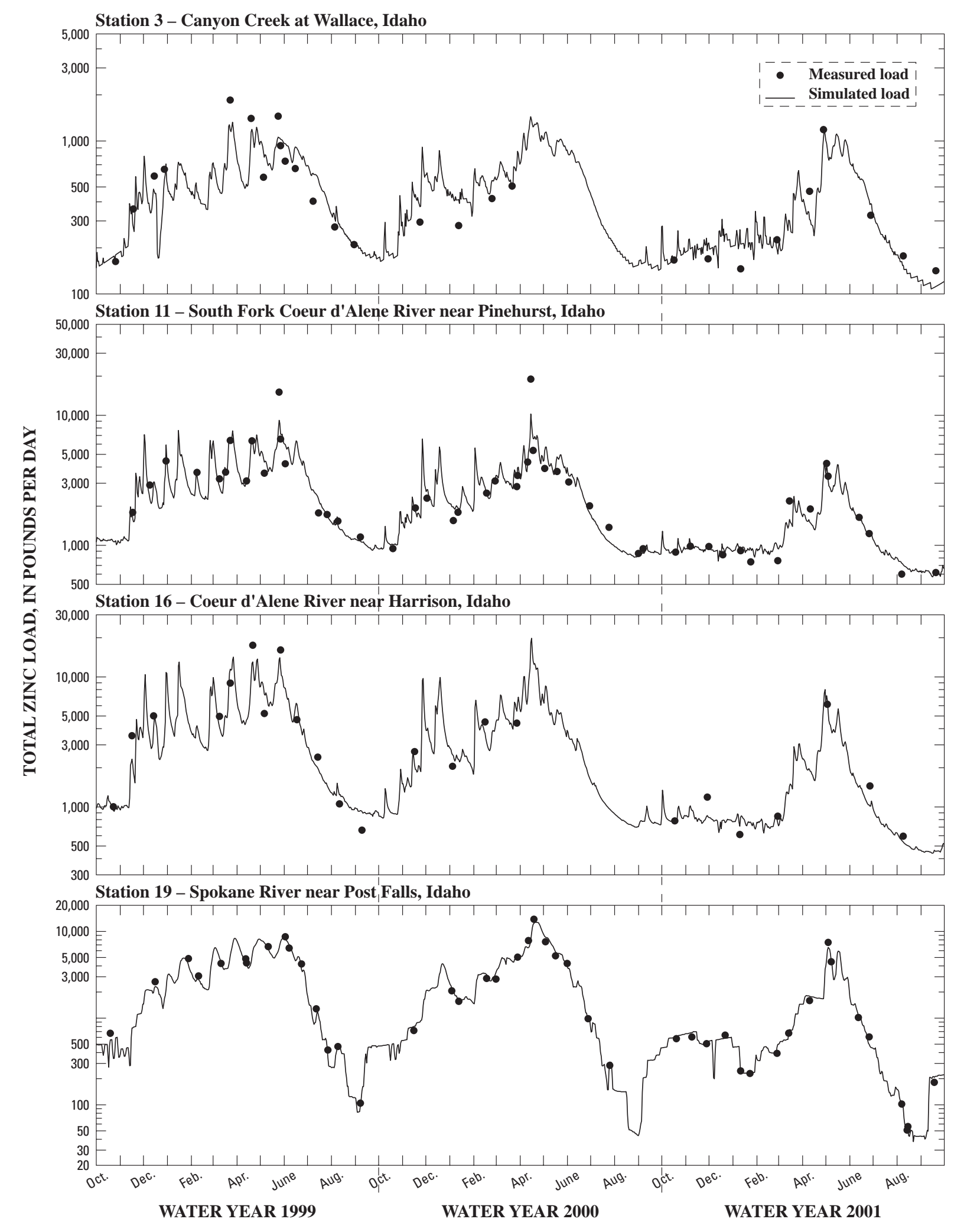

Figure 9. Measured and simulated loads of total zinc at four streamflow-gaging stations in the Spokane River Basin, Idaho and Washington, water years 1999-2001. (Locations shown in figures 1 and 2) 


\section{Trace-Metal Transport}

Annual loads of dissolved and total cadmium, lead, and zinc were simulated using the load models from table 2 and daily mean stream discharge for each station (table 4). Loads for WYs 1999 and 2000 were simulated for each of the 21 stations in the station network; data were sufficient to simulate loads for WY 2001 at only 9 stations. The mean daily stream discharge at the 21 stations decreased by an average of 12 percent from WY 1999 to WY 2000, and at the 9 stations with available data, decreased by an average of 58 percent from WY 2000 to WY 2001. At station 15 on the CDR near Cataldo, the annual mean discharge for WYs 1999-2001 represented about 126, 107, and 43 percent, respectively, of the historical (WYs 19112001) annual mean of $2,540 \mathrm{ft} 3 / \mathrm{s}$ (Brennan and others, 2002). At station 19 on the Spokane River at Post Falls, the annual mean discharge for WYs 1999-2001 represented about 121, 110, and 43 percent, respectively, of the historical (WYs 1913-2001) annual mean of 6,240 $\mathrm{ft}^{3} / \mathrm{s}$ (Brennan and others, 2002). Because stream discharge is a primary factor controlling trace-metal transport, changes in the annual mean discharge over the 3 years of sampling resulted in some large differences in annual trace-metal loads. At station 16 on the CDR near Harrison, the WY 1999 loads of total cadmium, lead, and zinc were 10,000, 470,000, and 1.5 million $\mathrm{lb}$, respectively. In WY 2001, the loads at station 16 were only $2,800,88,000$, and $480,000 \mathrm{lb}$, respectively, or a decrease of 72,81 , and 68 percent from the WY 1999 loads. In comparison, samples collected on February 10, 1996, during flooding in the CDR Basin (Beckwith, 1996) indicate 1-day loads of total cadmium, lead, and zinc at the station near Harrison of 2,400, 1.4 million, and 350,000 lb, respectively. These 1-day loads represented about 27 percent of the average annual cadmium load for WYs 1999-2000 (table 5), about 2.8 times the average annual lead load, and about 25 percent of the average annual zinc load near Harrison.

Whereas stream discharge increased incrementally at each successive station on the main stem from station 1 on the SFCDR downstream to station 21 on the Spokane River, the loads of total trace metals did not follow the same pattern (fig. 10). From station 1 near Mullan to station 16 on the CDR near Harrison, the trace-metal loads increased continuously as tributaries and other sources contributed stream discharge and trace metals to the SFCDR and the CDR. Primary tributary sources of trace-metal loads between station 1 on the SFCDR and station 16 on the CDR are Canyon Creek (station 3), Ninemile Creek (station 4), Government Gulch (station 9), Pine Creek (station 10), and the NFCDR (station 14). Although the combined stream discharge from Canyon Creek, Ninemile Creek, and Government Gulch was, on average, only $78 \mathrm{ft}^{3} / \mathrm{s}$ during WYs 1999 and 2000, these three tributaries contributed an average of about 3,000 lb/yr of cadmium, $23,000 \mathrm{lb} / \mathrm{yr}$ of lead, and 310,000 lb/yr of zinc to the SFCDR (figs. 11-13). Pine Creek and the NFCDR contributed an average of $2,320 \mathrm{ft}^{3} / \mathrm{s}$ of stream discharge and about $340 \mathrm{lb} / \mathrm{yr}$ of cadmium, 9,400 lb/yr of lead, and 79,000 lb/yr of zinc to the SFCDR.

Trace-metal loads decreased significantly between station 16 on the CDR near Harrison, through Coeur d'Alene Lake, and downstream to station 19 on the Spokane River near Post Falls (figs. 10-13). During WYs 1999 and 2000, the average loads at station 19 were about 4,600 lb/yr of cadmium, 44,000 lb/yr of lead, and 980,000 lb/yr of zinc. Between station 19 and station 21 at Long Lake, Washington, the trace-metal loads decreased further; average loads of total cadmium, lead, and zinc at station 21 were about 2,000, 24,000 , and 730,000 lb/yr, respectively.

\section{Trace-Metal Loading by Reach}

The source area contributing trace-metal loads measured at a station in the station network is the entire watershed upstream from that station. The network in the Spokane River Basin divides the basin into smaller subareas so that the load of metals contributed from specific areas can be determined. Thus, the relative importance of each subarea to the overall loading of trace metals to the Spokane River Basin can be estimated. Measurements at stations near the mouths of tributaries provide an estimate of integrated loads from the entire tributary watershed, and measurements at main-stem stations provide an estimate of incremental metal loading in a downstream manner. The station network also allows an approximation of the total load of trace metals discharged to Coeur d'Alene Lake, the load trapped within the lake, and the load moving through the lake and into the Spokane River.

The average annual incremental gains and (or) losses of stream discharge and trace-metal loads between main-stem stations on the SFCDR, CDR, and Spokane River from unmeasured sources were esti- 
Table 4. Simulated annual loads of cadmium, lead, and zinc at streamflow-gaging stations in the Spokane River Basin, Idaho and Washington, water years 1999-2001

[Loads were simulated using the equations from table 2; station locations shown in figures 1 and 2; No., number; USGS, U.S. Geological Survey; fts, cubic feet per second; SFCDR, South Fork Coeur d'Alene River; CDR, Coeur d'Alene River; NFCDR, North Fork Coeur d'Alene River; ID, Idaho; WA, Washington]

\begin{tabular}{|c|c|c|c|c|c|c|c|c|}
\hline \multirow[b]{2}{*}{$\begin{array}{l}\text { Station } \\
\text { No. }\end{array}$} & \multirow[b]{2}{*}{ USGS station name } & \multirow[b]{2}{*}{$\begin{array}{c}\text { Mean daily } \\
\text { stream discharge } \\
\left(\mathrm{ft}^{3} / \mathbf{s}\right)\end{array}$} & \multicolumn{6}{|c|}{ Water year 1999 simulated load, in pounds } \\
\hline & & & $\begin{array}{l}\text { Dissolved } \\
\text { cadmium }\end{array}$ & $\begin{array}{c}\text { Total } \\
\text { cadmium }\end{array}$ & $\begin{array}{l}\text { Dissolved } \\
\text { lead }\end{array}$ & $\begin{array}{l}\text { Total } \\
\text { lead }\end{array}$ & $\begin{array}{l}\text { Dissolved } \\
\text { zinc }\end{array}$ & Total zinc \\
\hline \multicolumn{9}{|c|}{ Main-stem stations } \\
\hline 1 & SFCDR above Deadman Gulch near Mullan, ID & 46 & 3 & 6 & 29 & 420 & 740 & 1,400 \\
\hline 6 & SFCDR at Silverton, ID & 268 & 2,500 & 2,600 & 3,700 & 40,000 & 320,000 & 320,000 \\
\hline 8 & SFCDR at Elizabeth Park near Kellogg, ID & 418 & 3,000 & 3,700 & 3,500 & 57,000 & 450,000 & 500,000 \\
\hline 11 & SFCDR near Pinehurst, ID & 687 & 6,600 & 7,900 & 5,800 & 130,000 & 930,000 & $1,100,000$ \\
\hline 15 & CDR near Cataldo, ID & 3,040 & 7,000 & 9,600 & 11,000 & 200,000 & $1,000,000$ & $1,300,000$ \\
\hline 16 & CDR near Harrison, ID & 3,050 & 7,700 & 10,000 & 38,000 & 470,000 & $1,200,000$ & $1,500,000$ \\
\hline 19 & Spokane River near Post Falls, ID & 7,530 & 3,900 & 5,000 & 6,100 & 46,000 & $1,000,000$ & $1,000,000$ \\
\hline 20 & Spokane River at 7-Mile Bridge, WA & 7,910 & 2,500 & 3,700 & 5,500 & 52,000 & 810,000 & 930,000 \\
\hline 21 & Spokane River at Long Lake, WA & 9,240 & 2,100 & 2,100 & 10,000 & 24,000 & 600,000 & 740,000 \\
\hline \multicolumn{9}{|c|}{ Tributary stations } \\
\hline 2 & Canyon Creek near Burke, ID & 40 & 3 & 6 & 47 & 120 & 590 & 700 \\
\hline 3 & Canyon Creek above mouth at Wallace, ID & 60 & 1,300 & 1,400 & 2,900 & 24,000 & 190,000 & 190,000 \\
\hline 4 & Ninemile Creek above mouth at Wallace, ID & 19 & 490 & 520 & 1,000 & 5,200 & 79,000 & 84,000 \\
\hline 5 & Placer Creek at Wallace, ID & 45 & 4 & 4 & 28 & 92 & 120 & 280 \\
\hline 7 & Moon Creek above mouth at Elk Creek, ID & 9 & 7 & 8 & 8 & 55 & 1,400 & 1,400 \\
\hline 9 & Government Gulch near mouth at Smelterville, ID & 4 & 1,100 & 1,100 & 49 & 200 & 35,000 & 36,000 \\
\hline 10 & Pine Creek below Amy Gulch near Pinehurst, ID & 197 & 130 & 140 & 200 & 1,300 & 36,000 & 35,000 \\
\hline 12 & NFCDR above Shoshone Creek near Prichard, ID & 836 & 85 & 52 & 120 & 390 & 2,500 & 3,800 \\
\hline 13 & Prichard Creek at mouth at Prichard, ID & 225 & 55 & 71 & 180 & 1,900 & 13,000 & 15,000 \\
\hline 14 & NFCDR at Enaville, ID & 2,240 & 160 & 230 & 390 & 6,500 & 23,000 & 48,000 \\
\hline 17 & St. Joe River at Calder, ID & 2,560 & 230 & 120 & 260 & 430 & 6,500 & 6,600 \\
\hline 18 & St. Maries River near Santa, ID & 435 & 60 & 9 & 190 & 460 & 2,400 & 2,200 \\
\hline
\end{tabular}




\begin{tabular}{|c|c|c|c|c|c|c|c|c|}
\hline \multirow[b]{2}{*}{$\begin{array}{c}\text { Station } \\
\text { No. }\end{array}$} & \multirow[b]{2}{*}{ USGS station name } & \multirow[b]{2}{*}{$\begin{array}{c}\text { Mean daily } \\
\text { stream discharge } \\
\left(\mathrm{ft}^{3} / \mathbf{s}\right)\end{array}$} & \multicolumn{6}{|c|}{ Water year 2000 simulated load, in pounds } \\
\hline & & & $\begin{array}{l}\text { Dissolved } \\
\text { cadmium }\end{array}$ & $\begin{array}{c}\text { Total } \\
\text { cadmium }\end{array}$ & $\begin{array}{c}\text { Dissolved } \\
\text { lead }\end{array}$ & $\begin{array}{l}\text { Total } \\
\text { lead }\end{array}$ & $\begin{array}{c}\text { Dissolved } \\
\text { zinc }\end{array}$ & Total zinc \\
\hline \multicolumn{9}{|c|}{ Main-stem stations } \\
\hline 1 & SFCDR above Deadman Gulch near Mullan, ID & 33 & 1 & 4 & 22 & 310 & 370 & 670 \\
\hline 6 & SFCDR at Silverton, ID & 216 & 1,600 & 1,800 & 3,200 & 21,000 & 290,000 & 300,000 \\
\hline 8 & SFCDR at Elizabeth Park near Kellogg, ID & 362 & 2,900 & 3,200 & 2,500 & 32,000 & 420,000 & 460,000 \\
\hline 11 & SFCDR near Pinehurst, ID & 584 & 5,700 & 6,400 & 4,300 & 74,000 & 830,000 & 930,000 \\
\hline 15 & CDR near Cataldo, ID & 2,710 & 5,600 & 8,900 & 6,200 & 210,000 & 830,000 & $1,000,000$ \\
\hline 16 & CDR near Harrison, ID & 2,730 & 6,200 & 7,700 & 34,000 & 530,000 & $1,000,000$ & $1,200,000$ \\
\hline 19 & Spokane River near Post Falls, ID & 6,850 & 3,300 & 4,200 & 6,000 & 42,000 & 890,000 & 970,000 \\
\hline 20 & Spokane River at 7-Mile Bridge, WA & 7,360 & 2,400 & 3,700 & 6,800 & 70,000 & 760,000 & 880,000 \\
\hline 21 & Spokane River at Long Lake, WA & 8,440 & 2,100 & 1,900 & 4,100 & 23,000 & 580,000 & 720,000 \\
\hline \multicolumn{9}{|c|}{ Tributary stations } \\
\hline 2 & Canyon Creek near Burke, ID & 35 & 2 & 4 & 41 & 140 & 420 & 410 \\
\hline 3 & Canyon Creek above mouth at Wallace, ID & 52 & 1,300 & 1,400 & 2,100 & 12,000 & 190,000 & 190,000 \\
\hline 4 & Ninemile Creek above mouth at Wallace, ID & 18 & 480 & 510 & 840 & 4,700 & 78,000 & 83,000 \\
\hline 5 & Placer Creek at Wallace, ID & 36 & 1 & 1 & 28 & 110 & 100 & 190 \\
\hline 7 & Moon Creek above mouth at Elk Creek, ID & 9 & 5 & 7 & 3 & 47 & 1,000 & 1,000 \\
\hline 9 & Government Gulch near mouth at Smelterville, ID & 3 & 1,000 & 1,000 & 46 & 160 & 33,000 & 34,000 \\
\hline 10 & Pine Creek below Amy Gulch near Pinehurst, ID & 164 & 110 & 110 & 160 & 1,100 & 28,000 & 31,000 \\
\hline 12 & NFCDR above Shoshone Creek near Prichard, ID & 756 & 25 & 6 & 110 & 390 & 2,200 & 3,700 \\
\hline 13 & Prichard Creek at mouth at Prichard, ID & 210 & 52 & 59 & 69 & 2,900 & 11,000 & 12,000 \\
\hline 14 & NFCDR at Enaville, ID & 2,030 & 140 & 210 & 380 & 10,000 & 20,000 & 44,000 \\
\hline 17 & St. Joe River at Calder, ID & 2,380 & 55 & 34 & 66 & 100 & 6,000 & 6,100 \\
\hline 18 & St. Maries River near Santa, ID & 391 & 60 & 8 & 170 & 340 & 2,100 & 2,000 \\
\hline
\end{tabular}


Table 4. Simulated annual loads of cadmium, lead, and zinc at streamflow-gaging stations in the Spokane River Basin, Idaho and Washington, water years 1999-2001-Continued

\begin{tabular}{|c|c|c|c|c|c|c|c|c|}
\hline \multirow[b]{2}{*}{$\begin{array}{c}\text { Station } \\
\text { No. }\end{array}$} & \multirow[b]{2}{*}{ Station name } & & \multicolumn{6}{|c|}{ Water year 2001 simulated load, in pounds } \\
\hline & & $\begin{array}{c}\text { Mean daily } \\
\text { stream discharge } \\
\left(\mathrm{ft}^{3} / \mathrm{s}\right)\end{array}$ & $\begin{array}{l}\text { Dissolved } \\
\text { cadmium }\end{array}$ & $\begin{array}{c}\text { Total } \\
\text { cadmium }\end{array}$ & $\begin{array}{c}\text { Dissolved } \\
\text { lead }\end{array}$ & $\begin{array}{l}\text { Total } \\
\text { lead }\end{array}$ & $\begin{array}{l}\text { Dissolved } \\
\text { zinc }\end{array}$ & Total zinc \\
\hline \multicolumn{9}{|c|}{ Main-stem stations } \\
\hline 8 & SFCDR at Elizabeth Park near Kellogg, ID & 138 & 1,500 & 1,500 & 1,000 & 3,400 & 220,000 & 220,000 \\
\hline 11 & SFCDR near Pinehurst, ID & 232 & 2,900 & 2,900 & 2,100 & 8,500 & 450,000 & 450,000 \\
\hline 16 & CDR near Harrison, ID & 1,060 & 2,200 & 2,800 & 11,000 & 88,000 & 460,000 & 480,000 \\
\hline 19 & Spokane River near Post Falls, ID & 2,690 & 1,000 & 1,200 & 1,300 & 8,800 & 280,000 & 320,000 \\
\hline 20 & Spokane River at 7-Mile Bridge, WA & 3,150 & 660 & 980 & 1,000 & 9,000 & 210,000 & 270,000 \\
\hline \multicolumn{9}{|c|}{ Tributary stations } \\
\hline 3 & Canyon Creek above mouth at Wallace, ID & 32 & 830 & 850 & 1,100 & 4,600 & 120,000 & 120,000 \\
\hline 4 & Ninemile Creek above mouth at Wallace, ID & 8 & 260 & 260 & 360 & 1,100 & 41,000 & 42,000 \\
\hline 10 & Pine Creek below Amy Gulch near Pinehurst, ID & 55 & 39 & 33 & 43 & 140 & 10,000 & 11,000 \\
\hline 14 & NFCDR at Enaville, ID & 763 & 56 & 62 & 110 & 360 & 6,900 & 11,600 \\
\hline
\end{tabular}


Table 5. Simulated mean annual loads of cadmium, lead, and zinc at streamflow-gaging stations in the Spokane River Basin, Idaho and Washington, water years 1999-2000

[Station locations shown in figures 1 and 2; No., number; USGS, U.S. Geological Survey; $\mathrm{ft}^{3} / \mathrm{s}$, cubic feet per second; SFCDR, South Fork Coeur d'Alene River; CDR, Coeur d'Alene River; NFCDR, North Fork Coeur d'Alene River; ID, Idaho; WA, Washington]

\begin{tabular}{|c|c|c|c|c|c|c|c|c|}
\hline \multirow[b]{2}{*}{ Station No. } & \multirow[b]{2}{*}{ USGS station name } & \multirow[b]{2}{*}{$\begin{array}{c}\text { Mean annual } \\
\text { stream discharge } \\
\left(\mathrm{ft}^{3} / \mathbf{s}\right)\end{array}$} & \multicolumn{6}{|c|}{ Simulated mean annual load, in pounds per year } \\
\hline & & & $\begin{array}{l}\text { Dissolved } \\
\text { cadmium }\end{array}$ & $\begin{array}{c}\text { Total } \\
\text { cadmium }\end{array}$ & $\begin{array}{l}\text { Dissolved } \\
\text { lead }\end{array}$ & Total lead & $\begin{array}{l}\text { Dissolved } \\
\text { zinc }\end{array}$ & Total zinc \\
\hline \multicolumn{9}{|c|}{ Main-stem stations } \\
\hline 1 & SFCDR above Deadman Gulch near Mullan, ID & 40 & 2 & 5 & 25 & 360 & 560 & 1,000 \\
\hline 6 & SFCDR at Silverton, ID & 242 & 2,000 & 2,200 & 3,400 & 30,000 & 300,000 & 310,000 \\
\hline 8 & SFCDR at Elizabeth Park near Kellogg, ID & 390 & 3,000 & 3,400 & 3,000 & 44,000 & 440,000 & 480,000 \\
\hline 11 & SFCDR near Pinehurst, ID & 636 & 6,200 & 7,200 & 5,000 & 100,000 & 880,000 & $1,000,000$ \\
\hline 15 & CDR near Cataldo, ID & 2,880 & 6,300 & 9,200 & 8,600 & 200,000 & 920,000 & $1,200,000$ \\
\hline 16 & CDR near Harrison, ID & 2,890 & 7,000 & 8,800 & 36,000 & 500,000 & $1,100,000$ & $1,400,000$ \\
\hline 19 & Spokane River near Post Falls, ID & 7,190 & 3,600 & 4,600 & 6,000 & 44,000 & 940,000 & 980,000 \\
\hline 20 & Spokane River at 7-Mile Bridge, WA & 7,640 & 2,400 & 3,700 & 6,200 & 61,000 & 780,000 & 900,000 \\
\hline \multicolumn{9}{|c|}{ Tributary stations } \\
\hline 2 & Canyon Creek near Burke, ID & 38 & 3 & 5 & 44 & 130 & 500 & 560 \\
\hline 3 & Canyon Creek above mouth at Wallace, ID & 56 & 1,300 & 1,400 & 2,500 & 18,000 & 190,000 & 190,000 \\
\hline 4 & Ninemile Creek above mouth at Wallace, ID & 18 & 480 & 520 & 920 & 5,000 & 78,000 & 84,000 \\
\hline 5 & Placer Creek at Wallace, ID & 40 & 2 & 2 & 28 & 100 & 110 & 240 \\
\hline 7 & Moon Creek above mouth at Elk Creek, ID & 9 & 6 & 7 & 5 & 51 & 1,200 & 1,200 \\
\hline 9 & Government Gulch near mouth at Smelterville, ID & 4 & 1,000 & 1,000 & 48 & 180 & 34,000 & 35,000 \\
\hline 10 & Pine Creek below Amy Gulch near Pinehurst, ID & 180 & 120 & 120 & 180 & 1,200 & 32,000 & 33,000 \\
\hline 12 & NFCDR above Shoshone Creek near Prichard, ID & 796 & 55 & 29 & 120 & 390 & 2,400 & 3,800 \\
\hline 13 & Prichard Creek at mouth at Prichard, ID & 217 & 54 & 65 & 120 & 2,400 & 12,000 & 14,000 \\
\hline 14 & NFCDR at Enaville, ID & 2,140 & 150 & 220 & 380 & 8,200 & 22,000 & 46,000 \\
\hline
\end{tabular}




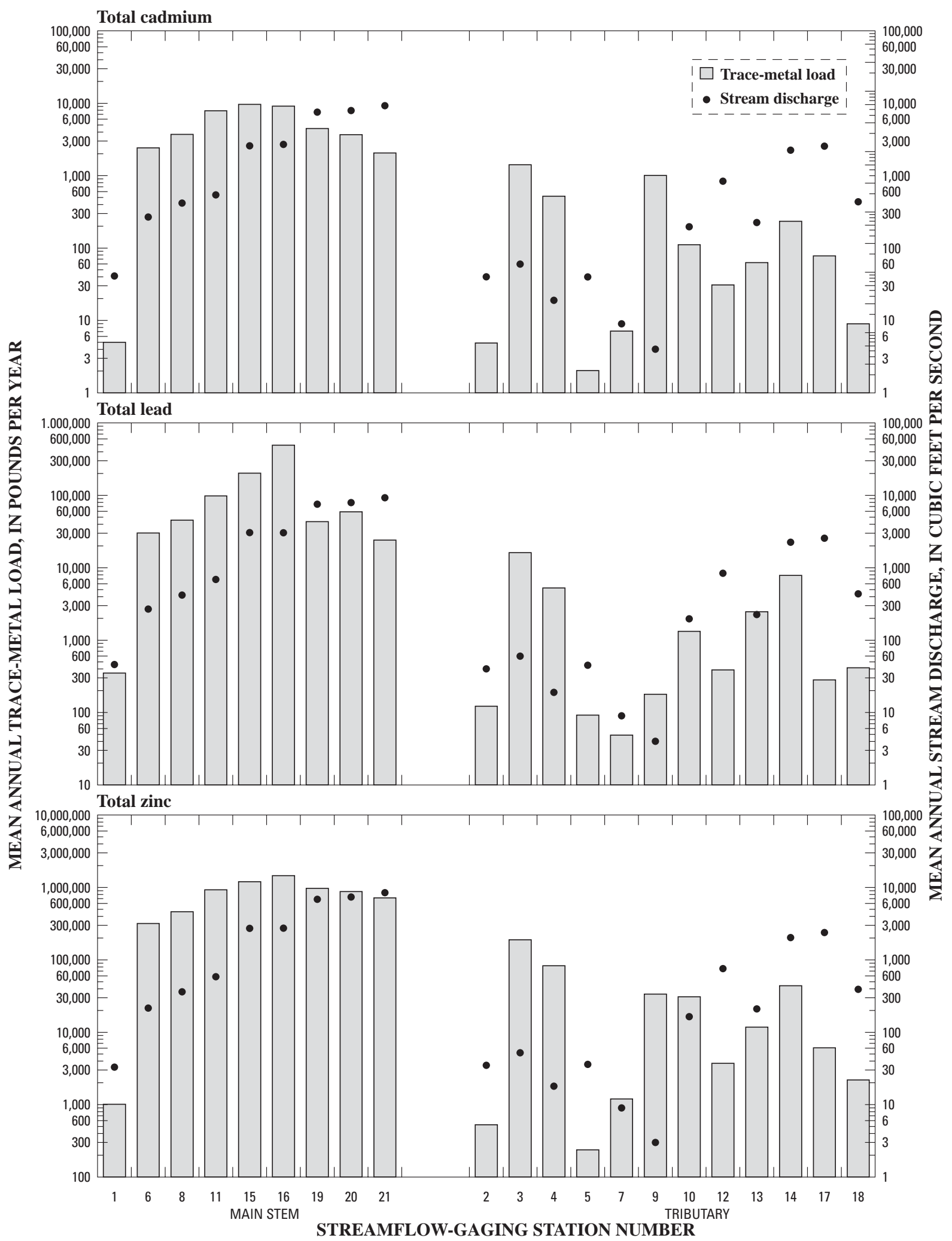

Figure 10. Mean annual stream discharge and mean annual loads of total cadmium, lead, and zinc at main-stem and tributary streamflow-gaging stations in the Spokane River Basin, Idaho and Washington, water years 1999-2000. (Locations shown in figures 1 and 2) 


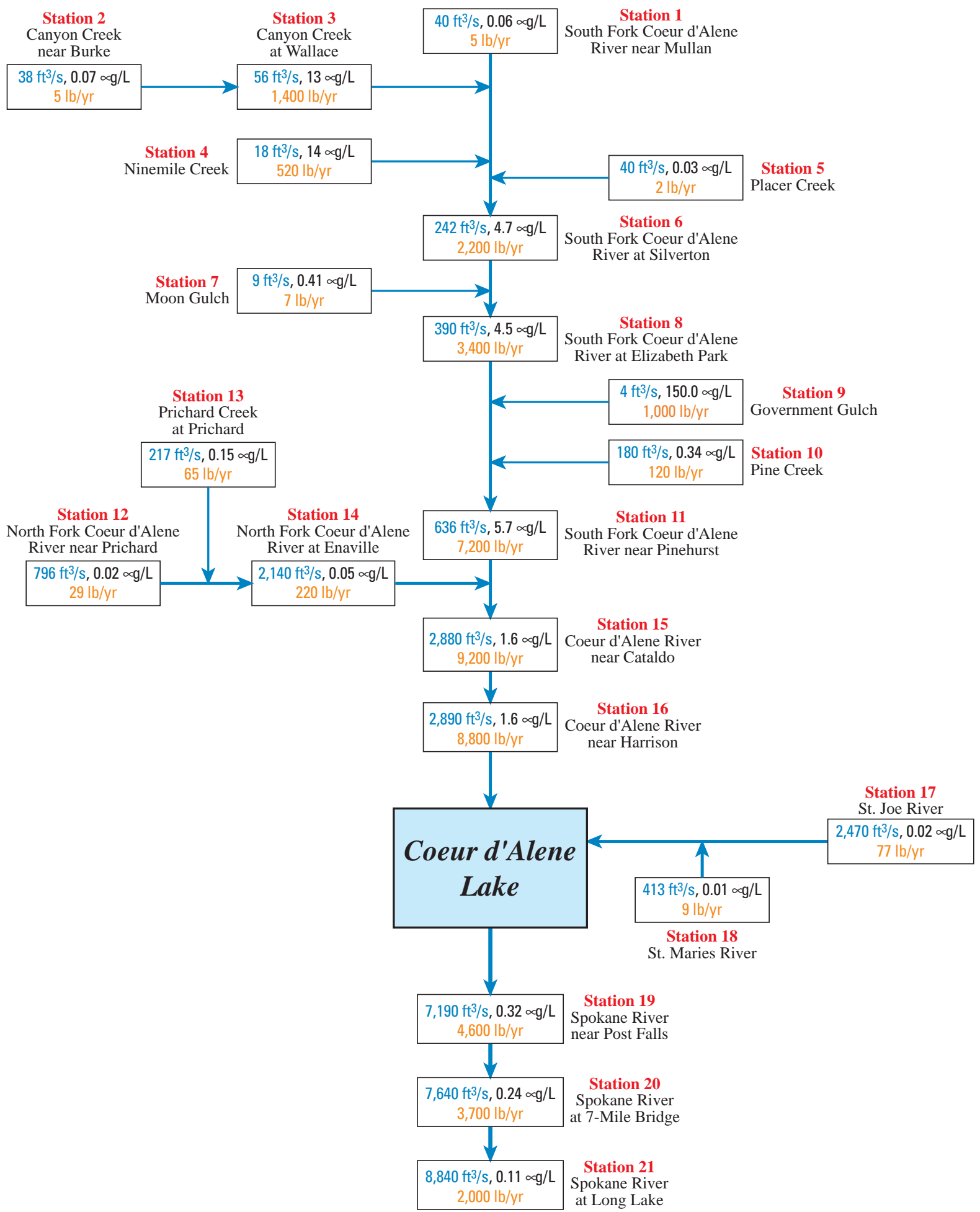

Figure 11. Mean annual stream discharge, mean flow-weighted concentration, and mean annual load of total cadmium for mainstem and tributary streamflow-gaging stations in the Spokane River Basin, Idaho and Washington, water years 1999-2000.

(Locations shown in figures 1 and 2 ; $\mathrm{ft}^{3} / \mathrm{s}$, cubic feet per second; $\mu \mathrm{g} / \mathrm{L}$, micrograms per liter; lb/yr, pounds per year) 


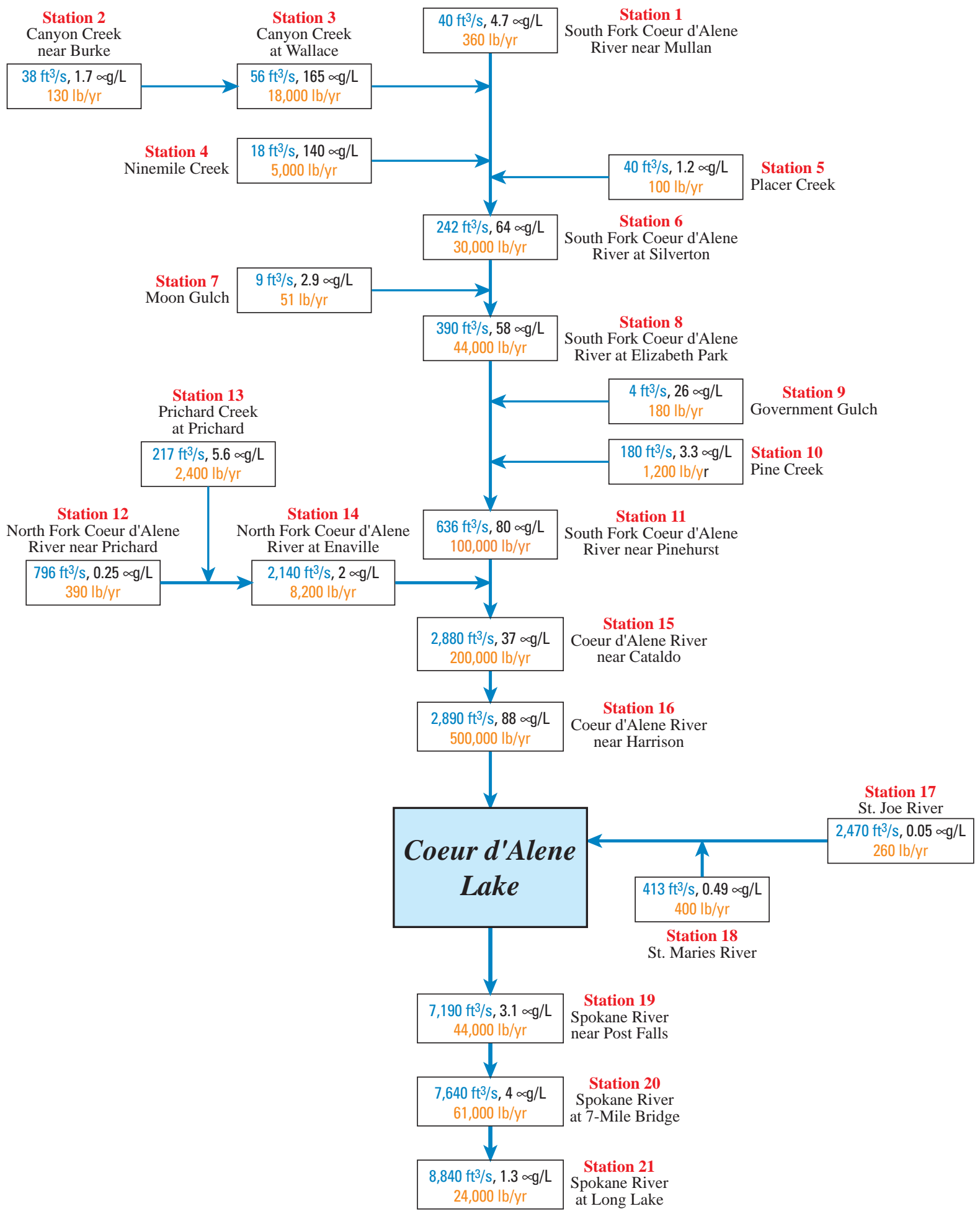

Figure 12. Mean annual stream discharge, mean flow-weighted concentration, and mean annual load of total lead for main-stem and tributary streamflow-gaging stations in the Spokane River Basin, Idaho and Washington, water years 1999-2000. (Locations shown in figures 1 and 2; $\mathrm{ft}^{3} / \mathrm{s}$, cubic feet per second; $\mu \mathrm{g} / \mathrm{L}$, micrograms per liter; lb/yr, pounds per year) 


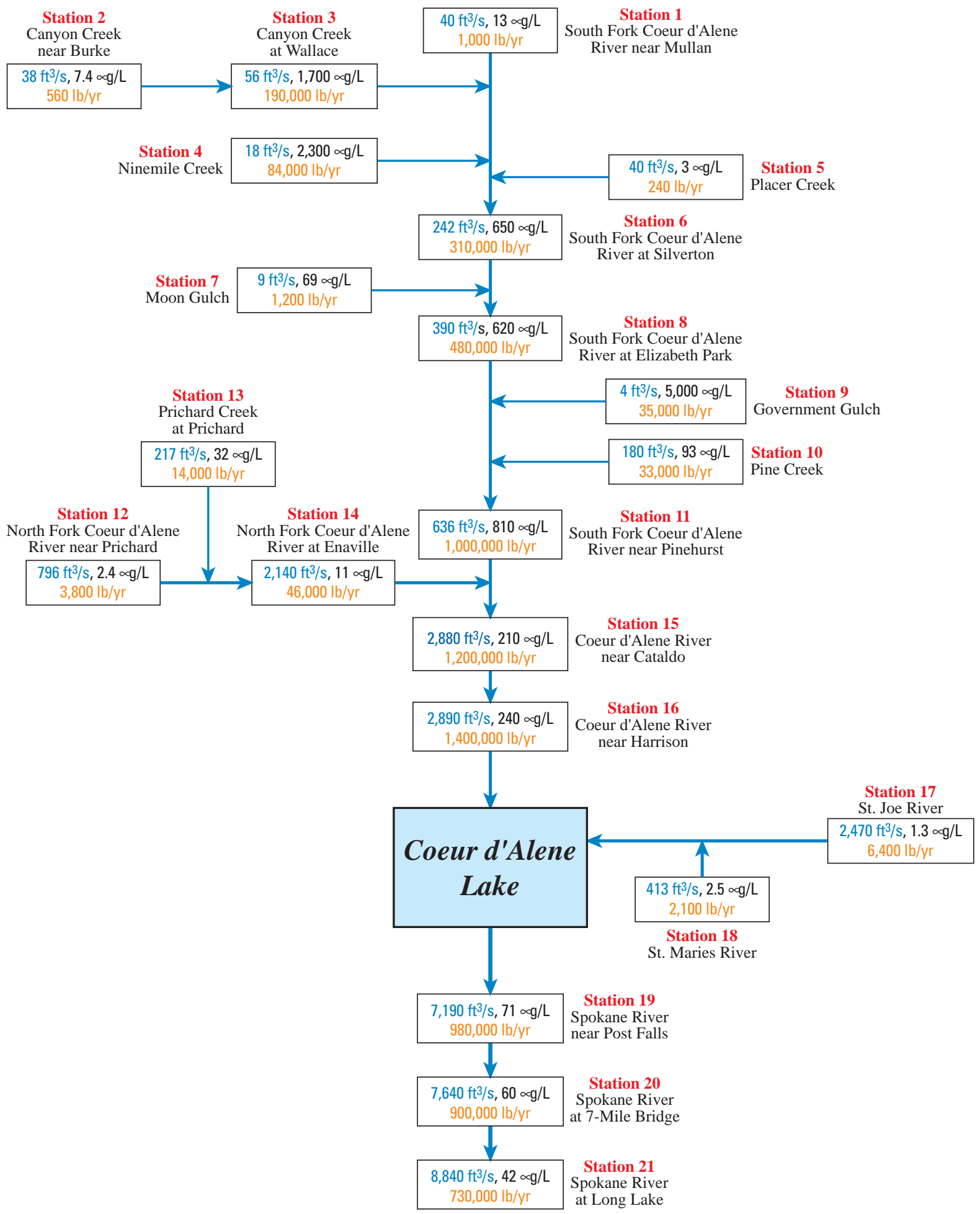

Figure 13. Mean annual stream discharge, mean flow-weighted concentration, and mean annual load of total zinc for main-stem and tributary streamflow-gaging stations in the Spokane River Basin, Idaho and Washington, water years 1999-2000. (Locations shown in figures 1 and $2 ; \mathrm{ft}^{3} / \mathrm{s}$, cubic feet per second; $\mu \mathrm{g} / \mathrm{L}$, micrograms per liter; $\mathrm{lb} / \mathrm{yr}$, pounds per year) 
mated for WYs 1999 and 2000 (table 6). The estimates were based on the differences in loads between mainstem stations and measured tributaries in the reach (figs. 11-13). The gains and (or) losses in stream discharge and loads that were unaccounted for by the station network are termed "unmeasured" in table 6. In main-stem reaches with both unmeasured stream discharge and unmeasured positive loads, the trace-metal concentration in the unmeasured stream discharge was estimated as the unmeasured load divided by the unmeasured stream discharge and appropriate conversion factors. Primary sources of unmeasured stream discharge and trace-metal loads in the Spokane River Basin are ungaged tributaries, ground-water discharge, overland flow, and dissolution and erosion of material in stream channels.

Stream discharge increased in all of the mainstem reaches; unmeasured sources accounted for at least part of the increase. Unmeasured stream discharge ranged from less than 1 percent in reach 5 between stations 15 and 16 to 36 percent in reaches 1 and 2 between stations 1 and 8 (table 6). Trace-metal loading (including the unmeasured loads) to main-stem reaches occurred primarily upstream from Coeur d'Alene Lake.

\section{SOUTH FORK COEUR D'ALENE RIVER}

Reach 1 includes the measured contributions from Canyon Creek and Ninemile Creek. Although these two tributaries contributed about 31 percent of the stream discharge measured at the downstream end of reach 1 (station 6), they accounted for about 87 percent of the cadmium, 77 percent of the lead, and 88 percent of the zinc loads at station 6 . About 36 percent of the stream discharge in reach 1 , and 14, 23, and 10 percent of the total cadmium, lead, and zinc loads, respectively, were from unmeasured sources. The relative percentages of unmeasured stream discharge and trace-metal loads in reach 1 indicate that, overall, unmeasured sources in reach 1 had smaller concentrations of total cadmium $(1.7 \mu \mathrm{g} / \mathrm{L})$, total lead $(40 \mu \mathrm{g} / \mathrm{L})$, and total zinc $(170 \mu \mathrm{g} / \mathrm{L})$ than did the measured sources draining mining-affected areas.

Unmeasured sources contributed an average of $139 \mathrm{ft}^{3} / \mathrm{s}$ (36 percent) of stream discharge to reach 2 , about 1,200 lb/yr (35 percent) of cadmium, 14,000 $\mathrm{lb} / \mathrm{yr}$ (32 percent) of lead, and 170,000 lb/yr (35 percent) of zinc. Estimated concentrations of total cad- mium, lead, and zinc in the unmeasured sources were $4.4,51$, and $620 \mu \mathrm{g} / \mathrm{L}$, respectively. On the basis of the percent contributions of stream discharge and tracemetal loads in reach 2, the trace-metal concentrations in the unmeasured sources were similar to those in the SFCDR in reach 2. A ground-water seepage study conducted along the SFCDR during low stream discharge in the summer and fall of 1999 documented that, in parts of reach 2, ground water contributed about 1 and $220 \mathrm{lb} / \mathrm{d}$ of cadmium and zinc, respectively, to the SFCDR (Barton, 2002). This ground-water contribution, if extrapolated over the 2-year period of study, would account for about 30 percent of the cadmium load and about 48 percent of the zinc load from unmeasured sources to reach 2. Although there was a net gain of $14,000 \mathrm{lb} / \mathrm{yr}$ of lead from unmeasured sources to reach 2, there was a loss of $400 \mathrm{lb} / \mathrm{yr}$ of dissolved lead. The ground-water seepage study documented a loss of dissolved lead of about $1.4 \mathrm{lb} / \mathrm{d}$ in reach 2 (Barton, 2002), similar in magnitude to the loss of $400 \mathrm{lb} / \mathrm{yr}$ (1.1 $\mathrm{lb} / \mathrm{d}$ ) shown in table 6 . Woods (2001b) suggested that losses of dissolved lead in the SFCDR are attributable to formation of a lead/iron complex and subsequent conversion to a particulate or colloidal form. During low stream discharge, this complex would be retained in the stream channel and subsequently transported downstream during increased stream discharge, thus accounting for at least part of the gain in the total load of lead in reach 2 .

Reach 3 of the SFCDR between station 8 at Elizabeth Park near Kellogg and station 11 near Pinehurst includes the Bunker Hill Superfund site (fig. 2). During 1999-2000, the loads of cadmium, lead, and zinc approximately doubled in the 8-mi length of the reach (table 6 and figs. 11-13). Government Gulch (station 9) and Pine Creek (station 10) contributed about 1,100 $\mathrm{lb} / \mathrm{yr}$ (15 percent) of cadmium, 1,400 lb/yr (1 percent) of lead, and $68,000 \mathrm{lb} / \mathrm{yr}$ (7 percent) of zinc to reach 3 . Unmeasured sources in reach 3 contributed about 62 $\mathrm{ft}^{3} / \mathrm{s}$ (10 percent) of stream discharge and about 2,700 lb/yr (38 percent) of cadmium, 55,000 lb/yr (55 percent) of lead, and 450,000 lb/yr (45 percent) of zinc to the SFCDR (table 6). On the basis of the 1999 seepage study described previously (Barton, 2002), groundwater recharge to reach 3 contributed about $2 \mathrm{lb} / \mathrm{d}$ of dissolved cadmium and $730 \mathrm{lb} / \mathrm{d}$ of dissolved zinc, primarily in a 2- to 4-mi reach of the SFCDR centered around Smelterville (fig. 2). Extrapolated to annual loads, the ground-water contributions of total cadmium 
Table 6. Mean annual gains and (or) losses of stream discharge and cadmium, lead, and zinc loads in main-stem reaches of the South Fork Coeur d'Alene, Coeur d'Alene, and Spokane Rivers, Idaho and Washington, water years 1999-2000

[Station locations shown in figures 1 and 2; negative stream discharge or load (number in bold) represents reach losses; $\mathrm{ft}^{3} / \mathrm{s}$, cubic feet per second; $\mu \mathrm{g} / \mathrm{L}$, micrograms per liter; NA, not applicable; - , no increase in stream discharge and (or) trace-metal load

\begin{tabular}{|c|c|c|c|c|c|c|c|}
\hline & \multirow[b]{2}{*}{$\begin{array}{c}\text { Mean annual } \\
\text { stream discharge } \\
\left(\mathrm{ft}^{3} / \mathbf{s}\right)\end{array}$} & \multicolumn{6}{|c|}{ Mean annual load, in pounds per year } \\
\hline & & $\begin{array}{l}\text { Dissolved } \\
\text { cadmium }\end{array}$ & $\begin{array}{c}\text { Total } \\
\text { cadmium }\end{array}$ & $\begin{array}{l}\text { Dissolved } \\
\text { lead }\end{array}$ & Total lead & $\begin{array}{l}\text { Dissolved } \\
\quad \text { zinc }\end{array}$ & Total zinc \\
\hline \multicolumn{8}{|c|}{ Reach 1: Station 1 to Station 6} \\
\hline $\begin{array}{r}\text { Sum of stations } 1,3,4 \text {, and } 5 \\
\text { Station } 6\end{array}$ & $\begin{array}{l}154 \\
242\end{array}$ & $\begin{array}{l}1,800 \\
2,000\end{array}$ & $\begin{array}{l}1,900 \\
2,200\end{array}$ & $\begin{array}{l}3,500 \\
3,400\end{array}$ & $\begin{array}{l}23,000 \\
30,000\end{array}$ & $\begin{array}{l}270,000 \\
300,000\end{array}$ & $\begin{array}{l}280,000 \\
310,000\end{array}$ \\
\hline Unmeasured stream discharge or load & 88 & 200 & 300 & -100 & 7,000 & 30,000 & 30,000 \\
\hline Amount unmeasured or lost in reach & $36 \%$ & $10 \%$ & $14 \%$ & $3 \%$ & $23 \%$ & $10 \%$ & $10 \%$ \\
\hline $\begin{array}{l}\text { Concentration of unmeasured stream } \\
\text { discharge }(\mu \mathrm{g} / \mathrm{L})\end{array}$ & NA & 1.2 & 1.7 & - & 40 & 170 & 170 \\
\hline \multicolumn{8}{|c|}{ Reach 2: Station 6 to Station 8} \\
\hline $\begin{array}{r}\text { Sum of stations } 6 \text { and } 7 \\
\text { Station } 8\end{array}$ & $\begin{array}{l}251 \\
390\end{array}$ & $\begin{array}{l}2,000 \\
3,000\end{array}$ & $\begin{array}{l}2,200 \\
3,400\end{array}$ & $\begin{array}{l}3,400 \\
3,000\end{array}$ & $\begin{array}{l}30,000 \\
44,000\end{array}$ & $\begin{array}{l}300,000 \\
440,000\end{array}$ & $\begin{array}{l}310,000 \\
480,000\end{array}$ \\
\hline Unmeasured stream discharge or load & 139 & 1,000 & 1,200 & -400 & 14,000 & 140,000 & 170,000 \\
\hline Amount unmeasured or lost in reach & $36 \%$ & $33 \%$ & $35 \%$ & $12 \%$ & $32 \%$ & $32 \%$ & $35 \%$ \\
\hline $\begin{array}{l}\text { Concentration of unmeasured stream } \\
\text { discharge }(\mu \mathrm{g} / \mathrm{L})\end{array}$ & NA & 3.7 & 4.4 & - & 51 & 510 & 620 \\
\hline \multicolumn{8}{|c|}{ Reach 3: Station 8 to Station 11} \\
\hline $\begin{array}{r}\text { Sum of stations } 8,9 \text {, and } 10 \\
\text { Station } 11\end{array}$ & $\begin{array}{l}574 \\
636\end{array}$ & $\begin{array}{l}4,100 \\
6,200\end{array}$ & $\begin{array}{l}4,500 \\
7,200\end{array}$ & $\begin{array}{l}3,200 \\
5,000\end{array}$ & $\begin{array}{r}45,000 \\
100,000\end{array}$ & $\begin{array}{l}510,000 \\
880,000\end{array}$ & $\begin{array}{r}550,000 \\
1,000,000\end{array}$ \\
\hline Unmeasured stream discharge or load & 62 & 2,100 & 2,700 & 1,800 & 55,000 & 370,000 & 450,000 \\
\hline Amount unmeasured or lost in reach & $10 \%$ & $34 \%$ & $38 \%$ & $36 \%$ & $55 \%$ & $42 \%$ & $45 \%$ \\
\hline $\begin{array}{l}\text { Concentration of unmeasured stream } \\
\text { discharge }(\mu \mathrm{g} / \mathrm{L})\end{array}$ & NA & 17 & 22 & 15 & 450 & 3,000 & 3,700 \\
\hline \multicolumn{8}{|c|}{ Reach 4: Station 11 to Station 15} \\
\hline Sum of stations 11 and 14 & 2,776 & 6,400 & 7,400 & 5,400 & 110,000 & 900,000 & $1,000,000$ \\
\hline Station 15 & 2,880 & 6,300 & 9,200 & 8,600 & 200,000 & 920,000 & $1,200,000$ \\
\hline Unmeasured stream discharge or load & 104 & -100 & 1,800 & 3,200 & 90,000 & 20,000 & 200,000 \\
\hline Amount unmeasured or lost in reach & $4 \%$ & $2 \%$ & $20 \%$ & $37 \%$ & $45 \%$ & $2 \%$ & $17 \%$ \\
\hline $\begin{array}{l}\text { Concentration of unmeasured stream } \\
\text { discharge }(\mu \mathrm{g} / \mathrm{L})\end{array}$ & NA & - & 8.8 & 16 & 440 & 97 & 970 \\
\hline
\end{tabular}


Table 6. Mean annual gains and (or) losses of stream discharge and cadmium, lead, and zinc loads in main-stem reaches of the South Fork Coeur d'Alene, Coeur d'Alene, and Spokane Rivers, Idaho and Washington, water years 1999-2000_Continued

\begin{tabular}{|c|c|c|c|c|c|c|c|}
\hline & \multirow[b]{2}{*}{$\begin{array}{c}\text { Mean annual } \\
\text { stream discharge } \\
\left(\mathrm{ft}^{3} / \mathrm{s}\right)\end{array}$} & \multicolumn{6}{|c|}{ Mean annual load, in pounds per year } \\
\hline & & $\begin{array}{l}\text { Dissolved } \\
\text { cadmium }\end{array}$ & $\begin{array}{c}\text { Total } \\
\text { cadmium }\end{array}$ & $\begin{array}{l}\text { Dissolved } \\
\text { lead }\end{array}$ & Total lead & $\begin{array}{l}\text { Dissolved } \\
\text { zinc }\end{array}$ & Total zinc \\
\hline \multicolumn{8}{|c|}{ Reach 5: Station 15 to Station 16} \\
\hline Station 15 & 2,880 & 6,300 & 9,200 & 8,600 & 200,000 & 920,000 & $1,200,000$ \\
\hline Station 16 & 2,890 & 7,000 & 8,800 & 36,000 & 500,000 & $1,100,000$ & $1,400,000$ \\
\hline Unmeasured stream discharge or load & 10 & 700 & -400 & 27,400 & 300,000 & 180,000 & 200,000 \\
\hline Amount unmeasured or lost in reach & $<1 \%$ & $10 \%$ & $4 \%$ & $76 \%$ & $60 \%$ & $16 \%$ & $14 \%$ \\
\hline $\begin{array}{l}\text { Concentration of unmeasured stream } \\
\text { discharge }(\mu \mathrm{g} / \mathrm{L})\end{array}$ & NA & - & - & - & - & - & - \\
\hline \multicolumn{8}{|c|}{ Reach 6: Station 16 to Station 19} \\
\hline Sum of stations 16,17 , and 18 & 5,773 & 7,200 & 8,900 & 36,000 & 500,000 & $1,100,000$ & $1,400,000$ \\
\hline Station 19 & 7,190 & 3,600 & 4,600 & 6,000 & 44,000 & 940,000 & 980,000 \\
\hline Unmeasured stream discharge or load & 1,417 & $-3,600$ & $-4,300$ & $-30,000$ & $-456,000$ & $-160,000$ & $-420,000$ \\
\hline Amount unmeasured or lost in reach & $20 \%$ & $50 \%$ & $48 \%$ & $83 \%$ & $91 \%$ & $15 \%$ & $30 \%$ \\
\hline $\begin{array}{l}\text { Concentration of unmeasured stream } \\
\text { discharge }(\mu \mathrm{g} / \mathrm{L})\end{array}$ & NA & - & - & - & - & - & - \\
\hline \multicolumn{8}{|c|}{ Reach 7: Station 19 to Station 20} \\
\hline Station 19 & 7,190 & 3,600 & 4,600 & 6,000 & 44,000 & 940,000 & 980,000 \\
\hline Station 20 & 7,640 & 2,400 & 3,700 & 6,200 & 61,000 & 780,000 & 900,000 \\
\hline Unmeasured stream discharge or load & 450 & $-1,200$ & -900 & 200 & 17,000 & $-160,000$ & $-80,000$ \\
\hline Amount unmeasured or lost in reach & $6 \%$ & $33 \%$ & $20 \%$ & $3 \%$ & $28 \%$ & $17 \%$ & $8 \%$ \\
\hline $\begin{array}{l}\text { Concentration of unmeasured stream } \\
\text { discharge }(\mu \mathrm{g} / \mathrm{L})\end{array}$ & NA & - & - & 0.2 & 19 & - & - \\
\hline \multicolumn{8}{|c|}{ Reach 8: Station 20 to Station 21} \\
\hline Station 20 & 7,640 & 2,400 & 3,700 & 6,200 & 61,000 & 780,000 & 900,000 \\
\hline Station 21 & 8,840 & 2,100 & 2,000 & 7,000 & 24,000 & 590,000 & 730,000 \\
\hline Unmeasured stream discharge or load & 1,200 & -300 & $-1,700$ & 800 & $-37,000$ & $-190,000$ & $-170,000$ \\
\hline Amount unmeasured or lost in reach & $14 \%$ & $13 \%$ & $46 \%$ & $11 \%$ & $61 \%$ & $24 \%$ & $19 \%$ \\
\hline $\begin{array}{l}\text { Concentration of unmeasured stream } \\
\text { discharge }(\mu \mathrm{g} / \mathrm{L})\end{array}$ & NA & - & - & 0.3 & - & - & - \\
\hline
\end{tabular}


and zinc to reach 3 would be 730 and 266,000 lb/yr, respectively, or 27 and 59 percent of the unmeasured loads.

\section{MAIN-STEM COEUR D'ALENE RIVER}

Combined, the NFCDR and SFCDR discharged about 7,400, 110,000, and 1 million lb/yr of total cadmium, lead, and zinc, respectively, during 1999-2000 (table 6 and figs. 11-13). Of these totals, the SFCDR accounted for about 97, 92, and 96 percent of the cadmium, lead, and zinc loads, respectively. The NFCDR and SFCDR contributed 96 percent of the stream discharge and 84,22 , and 75 percent, respectively, of the total cadmium, lead, and zinc loads measured $32 \mathrm{mi}$ downstream at station 16 on the CDR near Harrison (table 6). Unmeasured sources contributed about $390,000 \mathrm{lb} / \mathrm{yr}$ of lead (78 percent) and 400,000 lb/yr of zinc ( 29 percent) to reaches 4 and 5 (table 6). The hydrologic processes that appear to account for most of the lead entering reaches 4 and 5 are erosion and transport of sediment-bound lead contained in the river channel and banks. Lead-rich sediments containing at least 1,000 parts per million, or more than 30 times background concentrations, cover almost 75 percent of the CDR flood plain from the confluence of its North and South Forks to its mouth at Coeur d'Alene Lake (Bookstrom and others, 2001). The increase in zinc load in reaches 4 and 5 also may be derived from sediment or other particulate sources, or it may be contributed from ground-water discharge. The relatively small increase in stream discharge from unmeasured sources in reach 5 indicates that ground water is not a major source of stream discharge between stations 15 and 16 . However, if the river is losing water to and regaining water from the alluvial aquifer, dissolution of aquifer material may provide zinc to the CDR in reach 5. Further investigation would be necessary to determine whether this process provides the large increase in the zinc load in the lower reaches of the CDR.

\section{COEUR D'ALENE LAKE AND SPOKANE RIVER}

On the basis of annual loads in the CDR near Harrison (station 16), the St. Joe River at Calder (station 17), and the St. Maries River near Santa (station 18), Coeur d'Alene Lake received about $8,900 \mathrm{lb} / \mathrm{yr}$ of cadmium, 500,000 lb/yr of lead, and 1.4 million lb/yr of zinc during WYs 1999-2000. Although the CDR, as measured at station 16, contributed about half of the measured stream discharge to the lake, it contributed more than 99 percent of the cadmium, lead, and zinc loads, and the St. Maries and St. Joe Rivers combined contributed less than 1 percent. The loads transported from Coeur d'Alene Lake, as measured in the Spokane River near Post Falls (station 19) indicate that the lake retains a large part of the trace-metal loads that it receives. Horowitz and others (1995) estimated that about 82.5 million tons of trace-metal-enriched sediments have been deposited on or in the lakebed. The lake is especially efficient in trapping total lead, which is generally associated with sediment particles. Bookstrom and others (2001) estimated that about 300,000 tons of lead is present in the sediments on the lake bottom. Of the half million $\mathrm{lb} / \mathrm{yr}$ of lead entering the lake during $1999-2000$, only about $44,000 \mathrm{lb} / \mathrm{yr}$, or less than 10 percent, was transported from the lake into the Spokane River (fig. 12). Coeur d'Alene Lake is less efficient trapping cadmium and zinc than trapping lead. About 4,600 lb/yr of cadmium and 980,000 lb/yr of zinc, or about 52 and 70 percent of the loads entering the lake, respectively, were transported from the lake into the Spokane River (figs. 11 and 13).

In reach 7 between stations 19 and 20 on the Spokane River, there was a loss of 900 and 80,000 lb/yr of cadmium and zinc, respectively, and a gain of 17,000 lb/yr of lead (table 6 and figs. 11-13). In the upstream part of reach 7, depending on the streamflow conditions, the Spokane River may lose more than $500 \mathrm{ft}^{3} / \mathrm{s}$ of stream discharge to the underlying Spokane Valley/Rathdrum Prairie alluvial aquifer (Bolke and Vaccaro, 1981; Gearhart and Buchanan, 2000). This discharge from the Spokane River to the aquifer transports dissolved trace metals, primarily cadmium and zinc, as far as $200 \mathrm{ft}$ from the river margin (Marti and Garrigues, 2001). The cadmium and zinc transported to the aquifer probably account for most of the decrease in the loads between stations 19 and 20. In the downstream part of reach 7, the Spokane River becomes primarily a gaining reach as a result of the reversal in the stream/aquifer gradient, and the Spokane River receives recharge from the aquifer. Overall, annual mean stream discharge in reach 7 increased by 450 $\mathrm{ft}^{3} / \mathrm{s}$. However, cadmium and zinc were retained in the reach, possibly by sorption or precipitation processes within the aquifer (Rod Caldwell, U.S. Geological Survey, written commun., 2002). The increase in the lead load in reach 7 is probably attributable to mobilization and transport of sediment-bound lead deposited within 
the channel of the Spokane River. Concentrations of lead exceeding 1,000 parts per million in samples collected from the Spokane River near Post Falls (station 19) have been documented (Grosbois and others, 2001). Lead in the bed sediment of the Spokane River probably can be attributed to extreme floods in the CDR Basin. These floods transport large quantities of sediment-bound lead through Coeur d'Alene Lake and into the Spokane River (Grosbois and others, 2001; URS-Greiner, Inc. and CH2M-Hill, Inc, 2001).

Whereas stream discharge increased in reach 8 of the Spokane River by an average of 1,200 ft $3 / \mathrm{s}$ (14 percent) during 1999-2000, the loads of trace metals decreased. The loads of cadmium, lead, and zinc at station 21, located at the outlet of Long Lake (fig. 1), indicate that a large part of the trace-metal loads entering the lake are retained. Similar to Coeur d'Alene Lake, Long Lake appears especially efficient at trapping lead, which was reduced in reach 8 by about $37,000 \mathrm{lb} / \mathrm{yr}$ (61 percent) during WYs 1999-2000. About 2,000 lb/yr of cadmium, 24,000 lb/yr of lead, and 730,000 lb/yr of zinc were transported downstream from reach 8 toward the Columbia River (figs. 11-13). Overall, between the CDR near Harrison (station 16) and the Spokane River at Long Lake (station 21), about 6,800, 476,000, and $670,000 \mathrm{lb} / \mathrm{yr}$ of cadmium, lead, and zinc, respectively, were lost to Coeur d'Alene Lake, the Spokane River, and Long Lake. These losses represent about 76 percent of the cadmium load, 95 percent of the lead load, and 48 percent of the zinc load delivered to Coeur d'Alene Lake during WYs 1999-2000.

\section{CONCLUSIONS}

The results of this study confirm findings from previous investigations that have identified mining activities in mineralized areas of the South Fork Coeur d'Alene River (SFCDR) as the primary source of tracemetal-contaminated water and sediment in the SFCDR, Coeur d'Alene River (CDR), Coeur d'Alene Lake, and Spokane River. The transport of three trace metals of environmental concern (cadmium, lead, and zinc) was evaluated for water years 1999-2001 using an approach that quantified their concentrations and loads at 21 stations in the Spokane River Basin. The results demonstrate that during the 3 years of study, cadmium and zinc entering Coeur d'Alene Lake and transported downstream in the Spokane River were derived largely from the SFCDR Basin, primarily from mining- affected tributaries and the shallow alluvial aquifer adjacent to the SFCDR. Cadmium and zinc were transported in streams predominantly in the dissolved (less than 0.45 micrometer) form and, at most stations, concentrations were inversely correlated with stream discharge. In contrast to cadmium and zinc, lead was transported in streams primarily in the particulate form, and total lead concentration at all stations was positively correlated with stream discharge. Transport of lead occurs primarily during elevated stream discharge when lead-rich sediments stored in stream channels and the flood plain of the CDR are eroded and transported downstream.

The load models presented in this report are a valuable tool for assessing trace-metal transport in the Spokane River Basin. As additional data are collected, they can be integrated with existing data to modify the models and improve understanding of the relation between trace-metal concentrations and stream discharge. Future data collection activities targeted at extreme flow conditions (either high or low stream discharge) would provide essential data for understanding the mechanisms of trace-metal transport and estimating annual loads in the Spokane River Basin. In addition, continued sampling at stations such as the SFCDR near Pinehurst, the CDR near Harrison, and the Spokane River near Post Falls would provide data for evaluating trends and assessing the efficacy of remediation activities designed to reduce trace-metal loading to streams in the Spokane River Basin.

\section{REFERENCES CITED}

Aikaike, H., 1981, Likelihood of a model and information criterion: Journal of Econometrics, v. 16, p. 3-14.

Barton, G.J., 2002, Dissolved cadmium, zinc, and lead loads from ground-water seepage into the South Fork Coeur d'Alene River system, Northern Idaho, 1999: U.S. Geological Survey WaterResources Investigations Report 01-4274, 130 p.

Beckwith, M.A., 1996, Water-quality data collected during floods in the Coeur d'Alene River, Northern Idaho, February 1996: U.S. Geological Survey Fact Sheet FS-219-96, 4 p.

1998, Concepts for monitoring water quality in the Spokane River Basin, Northern Idaho and Eastern Washington: U.S. Geological Survey Open-File Report 98-534, 25 p. 
Bolke, E.L., and Vaccaro, J.J., 1981, Digital-model simulation of the hydrologic flow system, with emphasis on ground water, in the Spokane Valley, Washington and Idaho: U.S. Geological Survey Open-File Report 80-1300, 43 p.

Bookstrom, A.A., Box, S.E., Campbell, J.K., Foster, K.I., and Jackson, B.L., 2001, Lead-rich sediments, Coeur d'Alene River Valley, Idaho-area, volume, tonnage, and lead content: U.S. Geological Survey Open-File Report 01-140, 44 p.

Bortleson, G.C., Cox, S.E., Munn, M.D., Schumaker, R.J., Block, E.K., Bucy, L.R., and Cornelius, S.B., 1994, Sediment-quality assessment of Franklin D. Roosevelt Lake and the upstream reach of the Columbia River, Washington, 1992: U.S. Geological Survey Open-File Report 94-315, $130 \mathrm{p}$.

Bradu, D., and Mundlak, Y., 1970, Estimation in lognormal linear models: Journal of the American Statistical Association, v. 65, no. 329, p. 198211.

Brennan, T.S., Campbell, A.M., Lehmann, A.K., and O'Dell, I., 2002, Water resources data Idaho, water year 2001, vol. 2, Upper Columbia River Basin and Snake River Basin below King Hill: U.S. Geological Survey Water-Data Report ID01-2, $423 \mathrm{p}$.

Buchanan, T.J., and Somers, W.P., 1968, Stage measurements at gaging stations: U.S. Geological Survey Techniques of Water-Resources Investigations, book 3, chap. A7, 28 p.

1969, Discharge measurements at gaging stations: U.S. Geological Survey Techniques of Water-Resources Investigations, book 3, chap. A8, $65 \mathrm{p}$.

Carter, R.W., and Davidian, J., 1968, General procedure for gaging streams: U.S. Geological Survey Techniques of Water-Resources Investigations, book 3, chap. A6, 13 p.

Clark, G.M., and Woods, P.F., 2001, Transport of suspended and bedload sediment at eight stations in the Coeur d'Alene River Basin, Idaho: U.S. Geological Survey Open-File Report 00-472, 26 p.

Cohn, T.A., Caulder, D.L., Gilroy, E.J., Zynjuk, L.D., and Summers, R.M., 1992, The validity of a simple statistical model for estimating fluvial constituent loads - an empirial study involving nutrient loads entering Chesapeake Bay: Water Resources Research, v. 28, p. 2353-2363.

Cohn, T.A., Delong, L.L, Gilroy, E.J., Hirsch, R.M., and Wells, D.K., 1989, Estimating constituent loads: Water Resources Research, v. 25, p. 937942.

Crawford, C.G., 1991, Estimation of suspended-sediment rating curves and mean suspended-sediment loads: Journal of Hydrology, v. 129, p. 331-348.

Delong, L.L., Thompson, D.B., and Lee, J.K., 1997, The computer program FourPt (version 95.01) a model simulating one-dimensional, unsteady, open-channel flow: U.S. Geological Survey Water-Resources Investigations Report 97-4016, $69 \mathrm{p}$.

Dempster, A.P., Laird, N.M., and Rubin, D.B., 1977, Maximum likelihood from incomplete data via the EM algorithm: Journal of the Royal Statistical Society, Series B, v. 39, no. 1, p. 1-22.

Edwards, T.K., and Glysson, G.D., 1988, Field methods for measurement of fluvial sediment: U.S. Geological Survey Open-File Report 86-531, $118 \mathrm{p}$.

Fishman, J.J., ed., 1993, Methods of analysis by the U.S. Geological Survey National Water Quality Laboratory-determination of inorganic and organic constituents in water and fluvial sediments: U.S. Geological Survey Open-File Report 93-125, $217 \mathrm{p}$.

Fousek, R.S., 1996, Trace-element distributions in the sediments of the flood plain and river banks of the South Fork and Coeur d'Alene Rivers, Shoshone and Kootenai Counties, Idaho: Auburn, Ala., Auburn University, M.S. thesis, 310 p.

Friedman, L.C., and Erdmann, D.E., 1982, Quality assurance practices for the chemical and biological analyses of water and fluvial sediments: U.S. Geological Survey Techniques of Water Resources Investigations, book 5, chap. A6, $181 \mathrm{p}$.

Gearhart, C., and Buchanan, J.P., 2000, The hydraulic connection between the Spokane River and the Spokane Aquifer-gaining and losing reaches of the Spokane River from State Line, Idaho to Spokane, Washington: Spokane County Water Quality Management Program, $106 \mathrm{p}$.

Gilroy, E.J., Hirsch, R.M., and Cohn, T.A., 1990, Mean square error of regression-based constituent transport estimates: Water Resources Research, v. 26, p. 2069-2088.

Goolsby, D.A., Battaglin, W.A., Lawrence, G.B., Artz, R.S., Aulenbach, B.T., Hooper, R.P., Keeney, D.R., and Stensland, G.J., 1999, Flux and sources of nutrients in the Mississippi-Atchafalaya River Basin - topic 3 report for the integrated assess- 
ment on hypoxia in the Gulf of Mexico: Silver Spring, Md., NOAA Coastal Ocean Program Decision Analysis Series no. 17, 130 p.

Grosbois, C.A., Horowitz, A.J., Smith, J.J., and Elrick, K.A., 2001, The effect of mining and related activities on the sediment-trace element geochemistry of Lake Coeur d'Alene, Idaho, USA, Part III, Downstream effects- the Spokane River Basin: Hydrological Processes, v. 15, p. 855-875.

Hartz, M., 1993, Point and nonpoint source contributions of trace heavy metals to the South Fork Coeur d'Alene River, Shoshone County, Idaho, 1989-1990: Boise, Idaho Department of Health and Welfare, Division of Environmental Quality, Water Quality Status Report no. 111, 69 p.

Hirsch, R.M., Alley, W.M., and Wilber, W.G., 1988, Concepts for a national water-quality assessment: U.S. Geological Survey Circular 1021, 42 p.

Horowitz, A.J., Elrick, K.A., Robbins, J.A., and Cook, R.B., 1995, A summary of the effects of mining and related activities on the sediment-trace element geochemistry of Lake Coeur d'Alene, Idaho, USA: Journal of Geochemical Exploration, v. 52, p. 135-144.

Judge, C.G., Griffiths, W.E., Hill, R.C., Lutkepohl, H., and Lee, T.C., 1985, The theory and practice of econometrics: New York, John Wiley and Sons, p. 870-873.

Long, K.R., 1998, Production and disposal of mill tailings in the Coeur d'Alene mining region, Shoshone County, Idaho-preliminary estimates: U.S. Geological Survey Open-File Report 98$595,14 \mathrm{p}$.

Maret, T.R., and Skinner, K.D., 2000, Concentrations of selected trace elements in fish tissue and streambed sediment in the Clark Fork-Pend Oreille and Spokane River Basins, Washington, Idaho, and Montana, 1998: U.S. Geological Survey Water-Resources Investigations Report 00-4159, $26 \mathrm{p}$.

Marti, P.B., and Garrigues, R.S., 2001, Spokane River/Aquifer interaction project results, MayNovember 1999: Washington State Department of Ecology Report 01-03-024, 40 p.

Mueller, D.K., Martin, J.D., and Lopes, T.J., 1997, Quality-control design for surface-water sampling in the National Water-Quality Assessment Program: U.S. Geological Survey Open-File Report 97-223, 17 p.
Pritt, J.W., and Raese, J.W., eds., 1995, Quality assurance/quality control manual, National Water Quality Laboratory: U.S. Geological Survey Open-File Report 95-443, 35 p.

Smith, R.A., Alexander, R.B., and Wolman, M.G., 1987, Water-quality trends in the Nation's rivers: Science, v. 235, p. 1607-1615.

Spruill, T.B., 1993, Preliminary evaluation of hydrogeology and ground-water quality in valley sediments in the vicinity of Killarney Lake, Kootenai County, Idaho: U.S. Geological Survey WaterResources Investigations Report 93-4091, 41 p.

Tornes, L.H., 1997, National Water-Quality Assessment Program-Northern Rockies Intermontane Basins: U.S. Geological Survey Fact Sheet FS158-97, 4 p.

URS-Greiner, Inc. and CH2M-Hill, Inc., 2001, Remedial investigation report, Coeur d'Alene Basin, remedial investigation/feasibility study, vol. 1, part 7, Summary: Response action contract no. 68-W-98-228, prepared for U.S. Environmental Protection Agency, Region 10, variously paged.

U.S. Environmental Protection Agency, 1997, The incidence and severity of sediment contamination in surface waters of the United States, v. 1-3: Washington, D.C., U.S. Environmental Protection Agency, Office of Water, EPA 823-R-97-006, -007 , and -008 .

Wolynetz, M.S., 1979, Algorithm 139-maximum likelihood estimation in a linear model with confined and censored data: Applied Statistics, v. 28, p. 195-206.

Woods, P.F., 2001a, Concentrations and loads of cadmium, lead, and zinc measured on the ascending and descending limbs of the 1999 snowmelt-runoff hydrographs for nine water-quality stations, Coeur d'Alene River Basin, Idaho: U.S. Geological Survey Open-File Report 00-310, 42 p.

2001b, Concentrations and loads of cadmium, lead, and zinc measured during the 1999 water year within the Spokane River Basin, Idaho and Washington: U.S. Geological Survey Open-File Report 00-441, 32 p.

Woods, P.F., and Beckwith, M.A., 1997, Nutrient and trace-element enrichment of Coeur d'Alene Lake, Idaho: U.S. Geological Survey Water-Supply Paper 2485, 93 p. 
